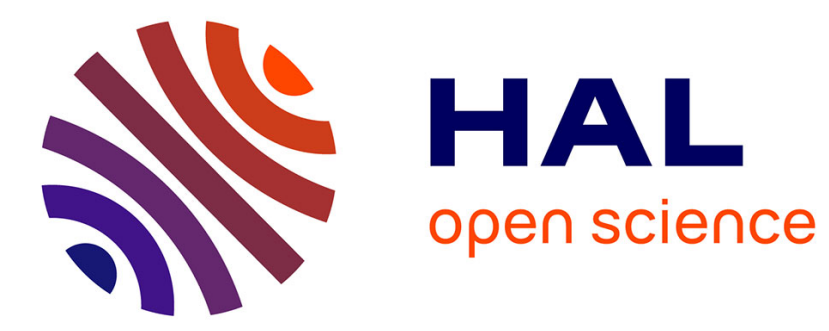

\title{
Source and origin of atmospheric trace elements entrapped in winter snow of the Italian Eastern Alps
}

P. Gabrielli, G. Cozzi, S. Torcini, P. Cescon, C. Barbante

\section{To cite this version:}

P. Gabrielli, G. Cozzi, S. Torcini, P. Cescon, C. Barbante. Source and origin of atmospheric trace elements entrapped in winter snow of the Italian Eastern Alps. Atmospheric Chemistry and Physics Discussions, 2006, 6 (5), pp.8781-8815. hal-00302116

\section{HAL Id: hal-00302116 https://hal.science/hal-00302116}

Submitted on 19 Sep 2006

HAL is a multi-disciplinary open access archive for the deposit and dissemination of scientific research documents, whether they are published or not. The documents may come from teaching and research institutions in France or abroad, or from public or private research centers.
L'archive ouverte pluridisciplinaire $\mathbf{H A L}$, est destinée au dépôt et à la diffusion de documents scientifiques de niveau recherche, publiés ou non, émanant des établissements d'enseignement et de recherche français ou étrangers, des laboratoires publics ou privés. 
Atmospheric trace elements in Alpine snow

\section{Source and origin of atmospheric trace elements entrapped in winter snow of the Italian Eastern Alps}

P. Gabrielli ${ }^{1}$, G. Cozzi ${ }^{2}$, S. Torcini ${ }^{3}$, P. Cescon ${ }^{1,2}$, and C. Barbante ${ }^{1,2}$

${ }^{1}$ Institute for the Dynamics of Environmental Processes-CNR, 30123 Venice, Italy

${ }^{2}$ Department of Environmental Sciences, University of Venice, Ca' Foscari, 30123 Venice, Italy

${ }^{3}$ ENEA, Casaccia, Roma, Via Anguillarese, 30100060 S.Maria di Galeria, Roma, Italy

Received: 14 June 2006 - Accepted: 13 July 2006 - Published: 19 September 2006

Correspondence to: C. Barbante (barbante@unive.it)

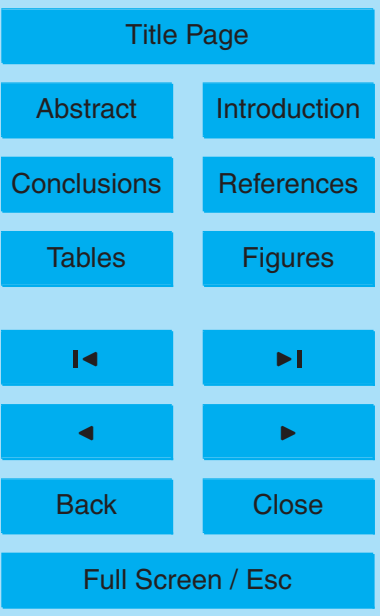

Printer-friendly Version

Interactive Discussion 


\section{Abstract}

Trace elements concentrations were determined in shallow snow samples from 21 sites in the Italian Eastern Alps in order to identify the sources of the contaminants present in the tropospheric winter boundary layer. The collection of superficial snow layers 5 was carried out weekly at altitudes between 1000 and $3000 \mathrm{~m}$ next to meteorological stations, far away from villages, roads and ski slopes. Ultra clean procedures were adopted in order to avoid contamination of the snow during the different experimental phases. Trace elements (Ag, Ba, Bi, Cd, Co, Cr, Cu, Fe, Mo, Mn, Pb, Sb, Ti, U, V and $\mathrm{Zn}$ ) were determined by Inductively Coupled Plasma Sector Field Mass Spectrometer

10 (ICP-SFMS). Ancillary parameters such as major ions $\left(\mathrm{SO}_{4}^{2-}, \mathrm{NO}_{3}^{-}, \mathrm{Ca}^{2+}, \mathrm{Mg}^{2+}, \mathrm{K}^{+}\right.$, $\mathrm{Na}^{+}, \mathrm{Cl}^{-}$) were measured by lon Chromatography (IC) and were useful in identifying the trace elements sources. The structure of the data was studied by using Principal Component Analysis (PCA) applied on the ranked data set matrix in order to minimize the weight of the outliers. Although concentrations were low at high altitudes in the 15 heart of the Alps, and higher at lower altitudes (Pre-Alps), the structure of the chemical content deposited by wet/dry mechanisms, resulted as rather uniform over the territory studied during the time considered. PCA shows that the chemical content of the snow is characterised by an anthropogenic component $\left(\mathrm{V}, \mathrm{Sb}, \mathrm{Zn}, \mathrm{Cd}, \mathrm{Mo}, \mathrm{Pb}, \mathrm{Ag}, \mathrm{Bi}, \mathrm{SO}_{4}^{2-}\right.$, $\mathrm{NO}_{3}^{-}$), mainly originating from the traffic in the adjacent Alpine valleys and the nearby 20 heavily industrialised area of the Po Valley, a crustal component $\left(\mathrm{Ca}^{2+}, \mathrm{Mg}^{2+}, \mathrm{Mn}, \mathrm{U}, \mathrm{Ti}\right.$, $\mathrm{Fe}, \mathrm{Cr}, \mathrm{Co}, \mathrm{Cu}$ and $\mathrm{Ba}$ ) mainly from the geological carbonate background (Dolomites) of the Eastern Alps, and a marine component $\left(\mathrm{Na}^{+}, \mathrm{Cl}^{-}\right)$from the Mediterranean Sea. It is likely that transport and mixing of trace elements in the winter boundary layer occurred at a local $(\sim 10 \mathrm{~km})$ and regional $(\sim 100 \mathrm{~km})$ scale, and was due not only to the 25 weak convection within the winter boundary layer but also to orographically induced winds and turbulences arising in the Alpine valleys due to the action of the synoptic wind.

\section{Atmospheric trace elements in Alpine snow}

P. Gabrielli et al.

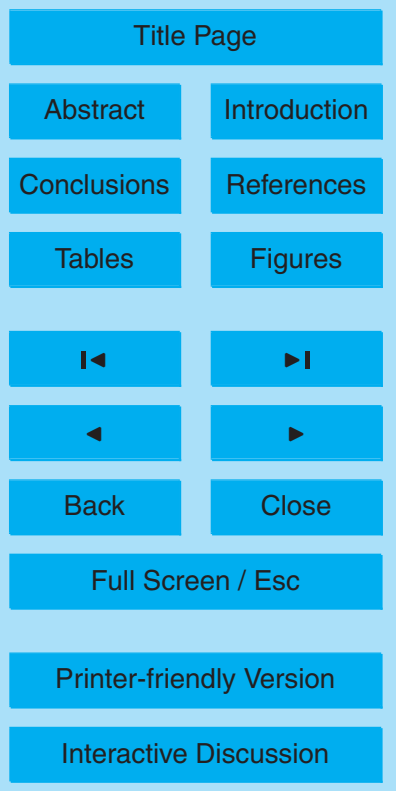




\section{Introduction}

Snow deposited on the Alps has the potential to provide valuable information on the atmospheric concentrations of short-living species, such as aerosol particles, and to document the effects of anthropogenic emissions on air in Europe (Schwikowski, 2003).

5 In fact, since snow crystals form in the clouds, they entrap aerosol particles called ice nuclei (Fuzzi, 1994). In addition, atmospheric water drops, containing condensation nuclei, can freeze on the surface of a snowflake (riming process) and, during their precipitation, can scavenge other particles below the clouds (aerosol scavenging) (Davidson, 1989). These mechanisms are widely known as wet deposition processes. Alternatively, aerosol particles are transported by wind turbulences and directly deposited onto the snow at the soil level (dry deposition process) (Cadle, 1991). This is the reason why the snow is characteristically marked by the chemical content both of the cloud generating air masses and by the aerosol particles contained in the troposphere during and after a precipitation event. In this context, snow concentrations reflect better 15 the atmospheric concentration in the case of wet deposition, whereas fluxes are better suited to describing atmospheric concentrations in the case of predominantly dry deposition (Alley et al., 1995).

Since the last decade the interest in the snow and ice contaminants has extended from studies conducted in the extremely remote polar site of Antarctica (Wolff Suttie, 1994; Gabrielli et al., 2005; Gaspari et al., 2006), Greenland (Hong et al., 1996; Barbante et al., 2003; Gabrielli et al., 2004) and the Arctic (Gauchard et al., 2004; Krachler et al., 2005; Shotyk et al., 2005) to cover the high altitude zones of different mountainous areas in the world such as remote sites in the Andes (Ferrari et al., 2001; Correia et al., 2003; Hong et al., 2004) and also those next to heavily populated areas such as the 25 European Alps (Van de Velde et al., 1998, 1999, 2000; Barbante et al., 2001a, 2002, 2004; Veysseyre et al., 2001). Although many studies, aiming at understanding the evolution of atmospheric contaminants in Europe during the past few centuries have been conducted on Alpine ice archives, studies regarding the present trace elements

\section{Atmospheric trace elements in Alpine snow}

P. Gabrielli et al.

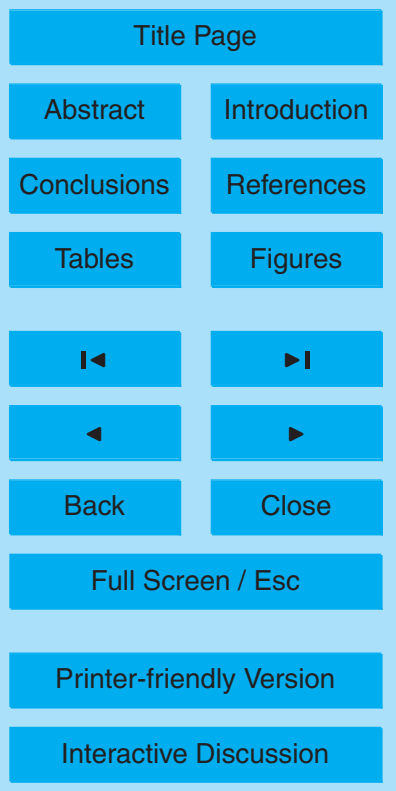


content of the Alpine snow are rare (Veysseyre et al., 2001). These kind of studies are extremely valuable because some contaminants can provide not only a better understanding of important global biogeochemical cycles but also because some are potentially very toxic to humans and to other organisms even at low concentrations.

5 Polar studies provide information about the presence of natural contaminants and pollutants in the global atmosphere (Barbante et al., 2001b; Planchon et al., 2002; Shotyk et al., 2005) and efforts on European Alpine Glaciers have been mainly devoted to the reconstruction of the history of trace elements pollution over the last few centuries (Barbante et al., 2004; Schwikowski et al., 2004). However, this study aims at 10 identifying these contaminants by focusing on a regional scale and offering a picture of the recent situation in the delicate and complex environment of the Alps. This mountain chain is a valuable observation point since it is located in the centre of Europe, one of the most densely populated and industrialised regions in the world. In addition, Alps are themselves very heavily influenced by man, especially by the international and re15 gional highways, industries, refuse incineration plants and also by the highest density of winter sport infrastructures for a mountain area in the world.

Due to the typically lower mixing heights during the winter, pollutants remain entrapped in the rather stable Alpine boundary layer, which extends its influence up to an altitude of $3000 \mathrm{~m}$ in the Eastern Alps (Kappeberger and Kerkmann, 1997) and does not allow an easy exchange between upper and lower levels. Thus we can expect the winter snow collected at an intermediate altitude in the Eastern Alps (up to $3000 \mathrm{~m}$ ) to be representative of the atmospheric chemical content of the lower Alpine troposphere and of the adjacent regions.

We collected shallow snow samples in the Italian Eastern Alps and we determined 25 trace elements ( $\mathrm{Ag}, \mathrm{Ba}, \mathrm{Bi}, \mathrm{Cd}, \mathrm{Co}, \mathrm{Cr}, \mathrm{Cu}, \mathrm{Fe}, \mathrm{Mo}, \mathrm{Mn}, \mathrm{Pb}, \mathrm{Sb}, \mathrm{Ti}, \mathrm{U}, \mathrm{V}$ and $\mathrm{Zn}$ ) and major ions $\left(\mathrm{SO}_{4}^{2-}, \mathrm{NO}_{3}^{-}, \mathrm{Ca}^{2+}, \mathrm{Mg}^{2+}, \mathrm{K}^{+}, \mathrm{Na}^{+}, \mathrm{Cl}^{-}\right)$in order to study directly the chemical composition of the snow and indirectly the structure and the sources of the contaminants present in the low Alpine troposphere. To have more specific information on the atmospheric path taken by the contaminants to reach the Alpine snowfield,

\section{Atmospheric trace elements in Alpine snow}

P. Gabrielli et al.

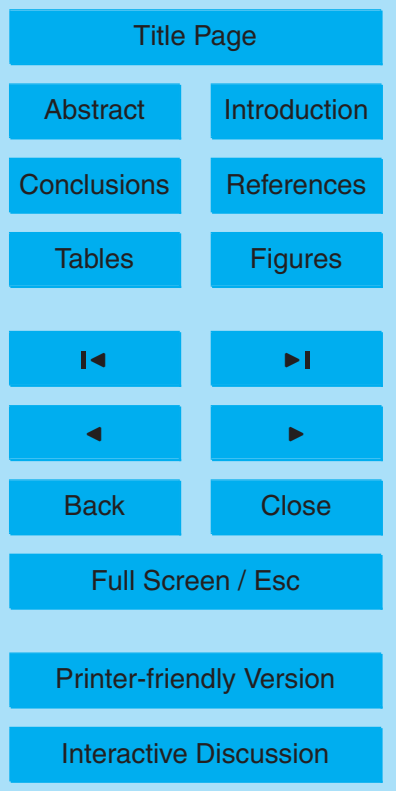


particular attention was paid to the relationship between the snow chemical content and the meteorological conditions.

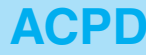

$6,8781-8815,2006$

\section{Experimental}

\subsection{Sampling sites}

5 Shallow snow samples were collected weekly from December 1997 to April 1998 in 21 sampling sites located in the North-East of Italy (see Fig. 1 and Table 1). This area has a surface of $\sim 15000 \mathrm{~km}^{2}$. The mean sampling site density was $1.4 \times 100 \mathrm{~km}^{2}$, which constitutes a high level of detail for this kind of study. This mountain area is approximately $100 \mathrm{~km}$ from the Gulf of Venice, and has a maximum elevation of $3905 \mathrm{~m}$ (Mount

Ortles). It is located on the southern slope of the Italian Eastern Alps, which is crossed by the important highway connecting Northern Europe with the south through the Brenner Pass in the Southern Tyrol. This territory is roughly divided into two main geological domains, the eastern part (the Dolomites) is characterised by carbonates (dolomite), whereas the western part (Mount Adamello and Mount Ortles groups) is mostly silicate

(granites and metamorphic rocks). During winter this area is normally characterized by an anti-cyclonic pressure field, whose influence is alternated with an Atlantic meteorological regime that conveys humid air masses to the southern Alpine slopes, producing snowfall events that often run concurrently with strong southern winds (Latini, 1987).

The 21 sampling sites were chosen mainly in rural/remote areas in order to avoid contamination from nearby sources of emissions such as roads, villages, tourist stations, Alpine huts and artificial snow guns. However, most of the sampling sites were close to ski areas at an average altitude of $\sim 1800 \mathrm{~m}$. The lowest site was located at $1040 \mathrm{~m}$ (Noana valley) and the highest at $3040 \mathrm{~m}$ (Mount Presena).

Each sampling site was chosen by proximity to manual and/or automatic meteoro25 logical stations, which recorded local meteorological parameters such as maximum, minimum and average temperature, average and maximum wind intensity, typology
Atmospheric trace elements in Alpine snow

P. Gabrielli et al.

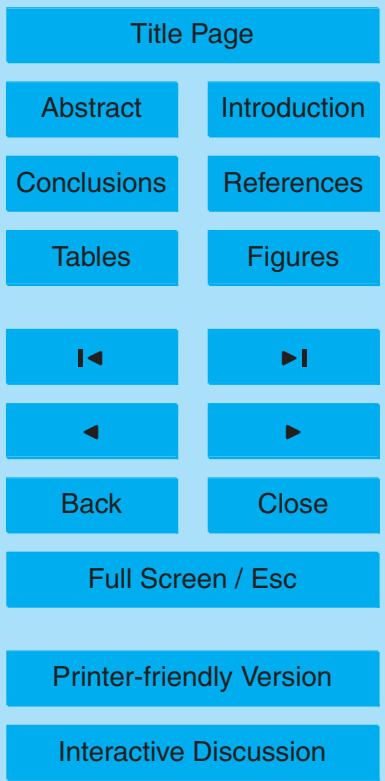


start/end time of snowfall/rain, depth of snow, quantity of rain and presence/absence of superficial rime. These data were ancillary to our data set and allowed us to have precise information, especially concerning precipitation and snow conditions. The territorial meteorological offices provided daily data, which were significant for the entire

5 sampling area, such as the wind velocity/intensity, the wind flow in the free troposphere (estimated from the on line station of Mount Pradazzo (Dolomites)), the vertical profile of temperature (at soil level, $1000,2000,3000 \mathrm{~m}$ ) and the altitude of the $0^{\circ} \mathrm{C}$ isotherm (from the radiosonde vertical profile in Udine).

\subsection{Sampling and materials}

10 Snow collection was carried out by adopting the stringent contamination free procedures used to sample the snow in Antarctica (Planchon et al., 2001). During the winter of 1998, shallow snow was collected weekly at all sites, obtaining a total amount of 366 samples. Operators wore special clean-room clothing and polyethylene gloves. Sampling was conducted by plunging low-density polyethylene (LDPE) ultra cleaned wide mouth bottles $(500 \mathrm{ml})$ directly into the snow, downwind of the technicians. The containers were then capped, sealed in double polyethylene bags and stored frozen until analysis (Barbante et al., 1997; Planchon et al., 2001).

LDPE sampling bottles were previously acid cleaned inside a class 100 clean bench installed inside a class 10000 clean room. For the acid cleaning we adopted a 520 step procedure (Barbante et al., 1997) using ultra pure water, obtained by coupling a reverse osmosis system (Milli-RO) with a four-column ion exchange system Milli-Q (Millipore, Bedford, MA), Merck "Suprapur" $\mathrm{HNO}_{3}$ (Merk, Darmstadt, Germany) and $\mathrm{HNO}_{3}(70 \%)$ doubly distilled at the National Institute of Standards and Technology (NIST, Gaithersburg, MD) were used for the acid cleaning stages. At the end of the 25 cleaning steps the LDPE bottles were rinsed three times and filled with ultra pure water for storage, the water was discarded just before snow collection at the sampling site.

\section{Atmospheric trace elements in Alpine snow}

P. Gabrielli et al.

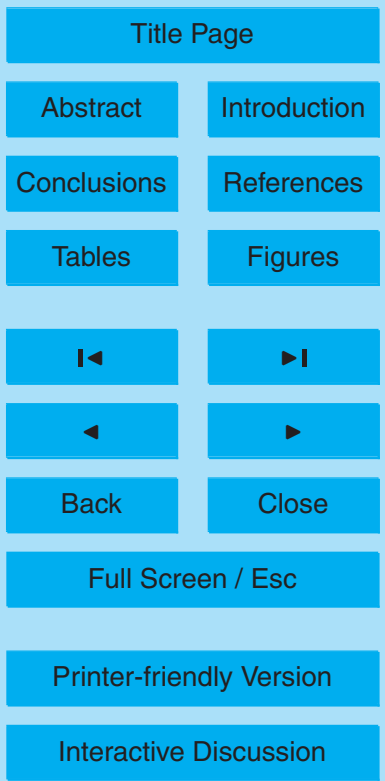


Samples were treated and melted in LDPE sampling bottles in a class 100 laminar flow clean bench inside a clean laboratory (Boutron, 1990). A $5 \mathrm{ml}$ aliquot was transferred in a $10 \mathrm{ml}$ ultra clean LDPE vial and acidified (2\%) with ultra pure concentrated $5 \mathrm{HNO}_{3}(\mathrm{NIST})$ for the quantification of $\mathrm{Ag}, \mathrm{Ba}, \mathrm{Bi}, \mathrm{Cd}, \mathrm{Co}, \mathrm{Cr}, \mathrm{Cu}, \mathrm{Fe}, \mathrm{Mo}, \mathrm{Mn}, \mathrm{Pb}$, $\mathrm{Sb}, \mathrm{Ti}, \mathrm{U}, \mathrm{V}$ and $\mathrm{Zn}$ by Inductively Coupled Plasma Sector Field Mass Spectrometry (ICP-SFMS) (Finnigan MAT Element, Thermo, Bremen, Germany) according to the procedure described by Barbante and co-workers (Barbante et al., 1999). The relative standard deviation ranged from $12 \%$ to $46 \%$ depending upon the metals and the concentration levels. Accuracy was verified by adopting the standard reference material SLRS-3 Riverine Water from the National Research Council of Canada. Working analytical conditions, blanks, accuracy and precision are described in detail elsewhere (Barbante et al., 1999).

$30 \mathrm{ml}$ aliquots were also taken in a $100 \mathrm{ml}$ ultraclean LDPE bottle for the determination of $\mathrm{SO}_{4}^{2-}, \mathrm{NO}_{3}^{-}, \mathrm{Ca}^{2+}, \mathrm{Mg}^{2+}, \mathrm{K}^{+}, \mathrm{Na}^{+}, \mathrm{Cl}^{-}$by lon Chromatography (IC), according to the procedure described in detail elsewhere (Gragnani et al., 1998), using a DIONEX AS5 column and $\mathrm{NaOH}$ (Baker) as eluant for anion determination and a DIONEX CS12 column with Methane sulphonic acid (MSA) as an eluant for the determination of cations. In addition a Cation Self Regenerating Suppressor (CSRSDIONEX) and an Anion Self Regenerating Suppressor (ASRS-DIONEX) were applied at the end of the columns. The relative standard deviation ranged from $0.5 \%$ to $9.2 \%$ depending upon the different species and ion concentration. Other analytical aspects are given in detail elsewhere (Gragnani et al., 1998).
Atmospheric trace elements in Alpine snow

P. Gabrielli et al.

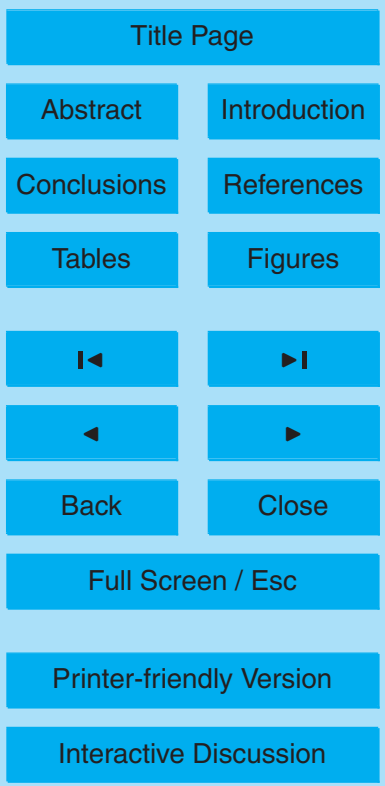




\section{Results and discussion}

\subsection{Main characteristics of the data set}

The main statistics of the chemical data set are given in Table 2. As expected, low average concentrations were found for trace elements, ranging from $8.6 \mathrm{ppt}$ of $U$ $5 \quad\left(1 \mathrm{ppt}=1 \mathrm{pg} \mathrm{g}^{-1}=10^{-12} \mathrm{~g} \mathrm{~g}^{-1}\right)$ up to $27 \mathrm{ppb}$ of Fe $\left(1 \mathrm{ppb}=1 \mathrm{ng} \mathrm{g}^{-1}=10^{-9} \mathrm{~g} \mathrm{~g}^{-1}\right)$, whereas higher mean values were determined for the major ions ranging between $\sim 900 \mathrm{ppb}$ of $\mathrm{NO}_{3}^{-}$and $\sim 100 \mathrm{ppb}$ for $\mathrm{Mg}^{2+}$.

In some cases, concentrations of some major ions were found to be below the detection limit. This mainly occurred for $\mathrm{K}^{+}$, which was determined only in 153 of the 366

10 samples. Looking at the distributions, median values represent in average $47 \%$ of the arithmetic mean; the mean skewness (positive asymmetry of the distribution) value is 7 and the mean kurtosis (indicating the distribution around a central value) is 70 . The chemical data set is therefore characterised by log normal like distributions.

In general, mean trace elements concentrations found on the Eastern Alps are higher

than those obtained by Veisseyre and co-workers (Veysseyre et al., 2001) in shallow snow samples taken in the French western Alps (1150-3532 m) at comparable altitudes. This is essentially due to the fact that in the Veyssyre's study, only fresh snow samples, representative of wet deposition, were considered. If we take the lowest Eastern Alps concentration values, which were determined in fresh snow samples as well, then concentrations found in the two studies are in good agreement. For example $\mathrm{Pb}$ shows a minimum concentration of $23 \mathrm{ppt}$ in a sample collected during the snow event recorded on 3 December 1997 at Mount Presena $(3020 \mathrm{~m})$ whereas minimum $\mathrm{Pb}$ concentration reported by Veisseyre and and co-workers was $65 \mathrm{ppt}$ at $3080 \mathrm{~m}$ in the Vallée Blanche (Mount Blanc, France). As previously observed (Veysseyre et al., 2001), trace elements concentrations in Alpine fresh snow collected at medium altitudes can be comparable to values determined in remote Greenland snow samples (Barbante et al., 2003). In the Eastern Alps, for instance, a minimum U concentration of $0.1 \mathrm{ppt}$ was found on 3 December on Mount Presena whereas in Greenland, the

Atmospheric trace elements in Alpine snow

P. Gabrielli et al.

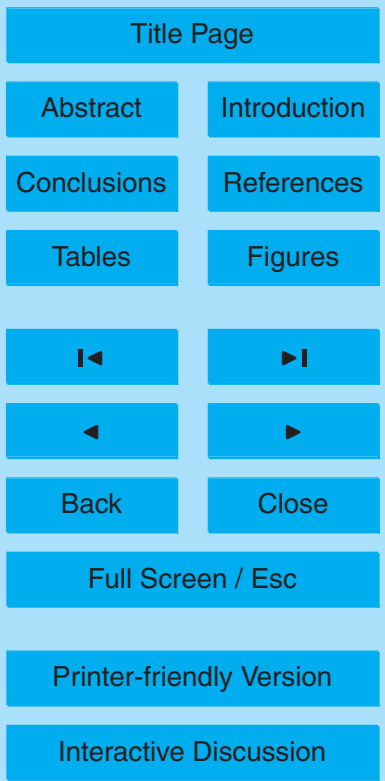


minimum $U$ concentration found in samples from a snow pit was $0.2 \mathrm{ppt}$ (Barbante et al., 2003).

In general, the Eastern Alps trace elements data set is more directly comparable with concentrations determined in relatively recent (after 1970) summer firn and ice, such

5 as those drilled at Colle Gnifetti (4450 m) (Mount Rosa, Swiss-Italian Western Alps), a particular Alpine site where summer snow accumulation is dominant (Barbante et al., 2004). For instance, mean $\mathrm{Zn}$ and $\mathrm{Cd}$ concentration were found to be $3176 \mathrm{ppt}$ and $58 \mathrm{ppt}$ on Colle Gnifetti, whereas at the lower altitudes of the Eastern Alps sampling sites, mean winter values of $\sim 3450 \mathrm{ppt}$ and $\sim 60 \mathrm{ppt}$ were determined. This similarity is 10 likely due to the fact that the trace elements content of summer snow taken on the high altitude Alpine glaciers and trace elements deposited on and within the winter snow layers of the lower Eastern Alps snow fields, originate from areas characterized by the same categories of emissions.

A strong vertical air mixing occurs in fact in the Alpine region especially during sum15 mer, that transports anthropogenic contaminants from cities, roads and industrialized areas, such as the Po valley for instance, upwards to $\sim 4000 \mathrm{~m}$ of altitude. In contrast during winter, the occurrence of a rather low altitude stable boundary layer, does not allow contaminants to reach the highest Alpine glaciers and confines them in this portion of troposphere. For example, winter firn/ice drilled above the winter boundary 20 layer, such those drilled at Dome du Gouter (4304 m, Mont Blanc, French-Italian western Alps), show much lower values (Van de Velde et al., 1998) than in summer. In this latter case, since winter snow concentrations are minimally influenced by regional emissions, they can represent a larger scale atmospheric trace element background. In contrast, summer Alpine snow at whatever altitude and Alpine winter snow within 25 the winter boundary layer (this study) are more likely to be representative of a regional $(\sim 10-100 \mathrm{~km})$ tropospheric background.

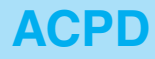

$6,8781-8815,2006$

Atmospheric trace elements in Alpine snow

P. Gabrielli et al.

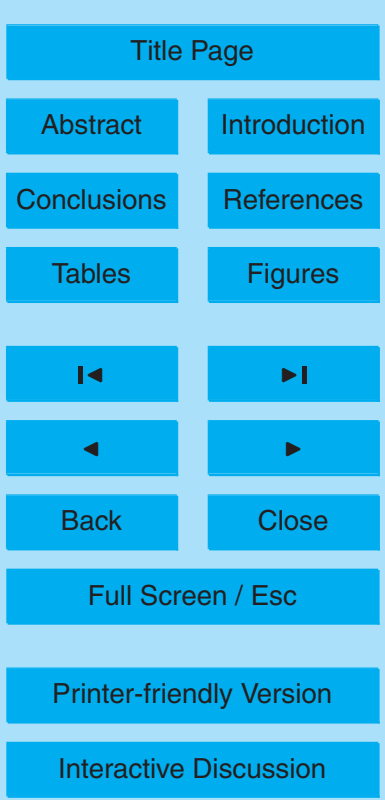


Snowfalls affected the entire territory from December until the first half of January and then again in April. In contrast, from the second half of January until the end of March, stable weather conditions were observed with a general lack of snowfall. Thus, wet de5 position occurred mainly in the first and in the last part of the sampling period whereas dry deposition dominated in-between. In general, for all trace elements and at all sampling sites, maximum concentrations were observed in periods characterized by dry deposition, whereas minimum concentrations coincided with wet deposition.

For instance, $\mathrm{Ba}$ concentrations determined in fresh and old (several weeks old) 10 snow samples, taken in Malga Bissina $(1780 \mathrm{~m})$, varied by 2-3 orders of magnitude from 0.05 up to $13 \mathrm{ppt}$ (see Fig. 2). Fe varied in a similar way at Folgarida $(1910 \mathrm{~m})$ from 0.1 up to $79 \mathrm{ppb}$. In general, trace elements temporal profiles were found to be redundant and concentrations varied by about 2-3 orders of magnitude depending only on whether snow samples were collected during or just after wet deposition events, or 15 after a period of dry deposition. The Ba profile reported in Fig. 2 is quite representative of the relative temporal variation of most of the trace elements in the whole territory considered. The only clear exception is $\mathrm{Cd}$, which generally varied by less than one order of magnitude during the sampling period as can be shown, for instance, from snow samples collected on the Mounts of Ornella $(2250 \mathrm{~m})$ where Cd concentration values varied only from $0.02 \mathrm{ppb}$ up to $0.07 \mathrm{ppb}$ during the field season.

The long dry deposition period during February and March, which was broken only by two minor snow events on 23 February and on 23 March, offers the possibility of estimating the dry fluxes of trace elements and species to the Eastern Alps. For this investigation, concentration data from the four highest sampling sites were selected. 25 This minimized the influence of local contamination and ruled out the possibility of percolation of molten snow that would have modified the original analyte concentrations (Davis, 1991). Data from Mount Presena (3040 m), Ravales (2615 m), Mounts of Ornella $(2250 \mathrm{~m})$ and Mount Pradazzo $(2200 \mathrm{~m})$ were thus selected specifically dur-

\section{Atmospheric trace elements in Alpine snow}

P. Gabrielli et al.

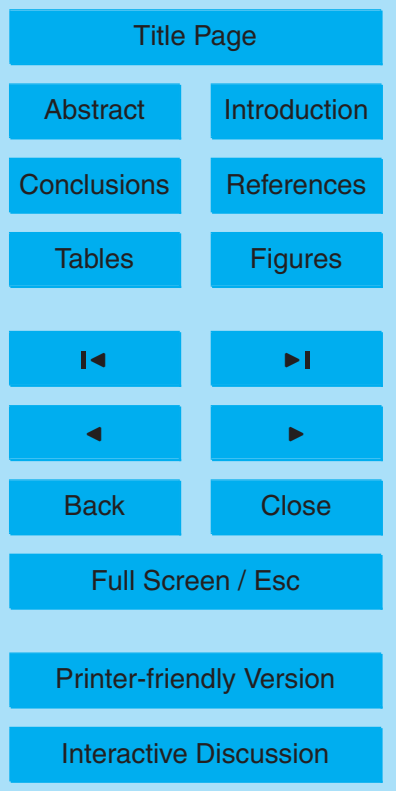


ing two time periods when the maximum temperature was continuously below $0^{\circ} \mathrm{C}(19$ January-4 February ; 24 February-11 March. The flux $(F)$ was obtained as:

$F=\left\{(\Delta C / \Delta t)_{m}\right\} \times \rho \times h$

where $(\Delta \mathrm{C} / \Delta \mathrm{t})_{m}$ is the mean difference of concentration of samples collected in suc5 cessive week, $\rho$ is the mean snow density $\left(\sim 300 \mathrm{~kg} \mathrm{~m}^{-3}\right)$ and $\mathrm{h}$ the height of the snow layer sampled $(\sim 2 \mathrm{~cm})$.

Fluxes obtained for each trace element and ions are reported in Table 3. It should be noted that the fluxes calculated over the two different periods show on average a deviation of only $\sim 24 \%$, which can be considered for most of the trace elements and ions within the range experimental error. It is also interesting to compare the fluxes found for trace elements and major ions with the critical loads that are available for these ecosystems in the literature (Posch et al., 2005). Critical loads of $\mathrm{Pb}$ and $\mathrm{Cd}$ for forests and soils are 10 and $1 \mathrm{~g} \mathrm{ha}^{-1} \mathrm{y}^{-1}$ whereas $\mathrm{Pb}$ and $\mathrm{Cd}$ fluxes to the Eastern Alps are estimated to be 4.2 and $0.09 \mathrm{~g} \mathrm{ha}^{-1} \mathrm{y}^{-1}$, respectively. For $\mathrm{S}$ and $\mathrm{N}$ the critical loads 15 in alpine and sub-alpine grassland are 39 and $42 \mathrm{~kg} \mathrm{ha}^{-1} \mathrm{y}^{-1}$ whereas $\mathrm{S}$ and $\mathrm{N}$ fluxes (estimated from the fallout of sulphate and nitrate only) are 0.44 and $0.63 \mathrm{~kg} \mathrm{ha}^{-1} \mathrm{y}^{-1}$. It can be observed that trace elements and major ions fluxes are significantly below the critical loads, with the exception of $\mathrm{Pb}$, indicating that it needs to be more carefully monitored in the future.

\subsection{Spatial variability}

The spatial variability of the average concentrations is illustrated in Table 4. This is very high, reflecting the heterogeneity of the sampling sites due to their different altitudes, geographic positions and distances from anthropogenic sources of emission. In general the lowest concentrations are found in snow collected at more than $2000 \mathrm{~m}$ of altitude, whereas higher concentrations are determined in snow taken at low-medium altitudes and especially in the Pre-Alps. For instance, mean V concentrations on Mount Pradazzo (2200 m) were 0.08 ppb, on Mount Vioz (2030 m) 0.09 ppb, on

Atmospheric trace elements in Alpine snow

P. Gabrielli et al.

Title Page

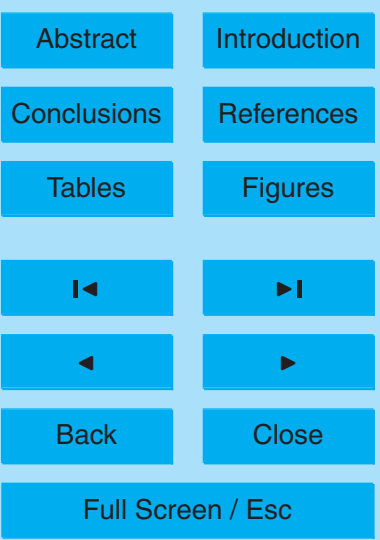

Printer-friendly Version

Interactive Discussion 
Mounts Ornella (2250 m) $0.1 \mathrm{ppb}$ and on Presena Summit (3040 m) $0.1 \mathrm{ppb}$ whereas at Viote $(1500 \mathrm{~m})$ it was $0.23 \mathrm{ppb}$, on Mount Grappa $(1540 \mathrm{~m}) 0.4 \mathrm{ppb}$ and in Faverghera (1605 m) $0.5 \mathrm{ppb}$.

Our results are in contrast with other studies performed by determining heavy metal 5 concentrations in mosses sampled on the Alps. They observed in fact the highest concentrations at mid altitudes (1400-1800 m) (Gerdol, Bragazza, 2006) or reported a remarkable increase in heavy metals concentrations with rising altitude (Zechmeister, 1995) (these two studies both occurred in late summer). The decrease of concentrations values concomitant to the increasing altitude observed in our study can be 10 explained by first considering that the higher Alpine sites are less influenced by the anthropogenic emissions originating from the adjacent Alpine valleys (Veysseyre et al., 2001) and secondly that snow accumulation at higher altitudes is likely to be higher than at lower altitudes, causing a dilution effect. Very high concentrations on the PreAlps can be explained by taking into account the proximity of the Pre Alpine sites to the

15 Po valley, the most extended industrialised area of Italy, that probably heavily contaminates the closest sub Alpine areas.

High concentrations are observed sometimes also at rather elevated Alpine sites but in these few cases this observation is explained by the presence of local intense anthropogenic sources, which strongly influenced the chemical composition of the snow, especially during the dry deposition periods. This is the case of the Tonale Pass (1860 m) snow samples that were certainly influenced by the emissions from the intense traffic of the adjacent $(\sim 1 \mathrm{~km})$ tourist station. This is also the case for the snowfield of Ravales in the Dolomites. This station is at $2615 \mathrm{~m}$ of altitude and is exactly above the very important tourist station of Cortina d'Ampezzo (1200 m). In Ravales, average concentrations of $3.3 \mathrm{ppb}$ of $\mathrm{Zn}, 3.8 \mathrm{ppb}$ of $\mathrm{Ti}, 0.052 \mathrm{ppb}$ of $\mathrm{Sb}$ and $0.30 \mathrm{ppb}$ of $\mathrm{Cu}$ were found. In comparison, at the heavily anthropized Tonale Pass, average concentrations of $7.4 \mathrm{ppb}$ of $\mathrm{Zn}, 9.3 \mathrm{ppb}$ of $\mathrm{Ti}, 0.56 \mathrm{ppb}$ of $\mathrm{Sb}$ and $3.13 \mathrm{ppb}$ of $\mathrm{Cu}$ were found, whereas at the remote site of Val Noana $(1025 \mathrm{~m}) 0.6 \mathrm{ppb}$ of $\mathrm{Zn}, 1.3 \mathrm{ppb}$ of Ti, $0.027 \mathrm{ppb}$ of $\mathrm{Sb}$ and $0.17 \mathrm{ppb}$ of $\mathrm{Cu}$ were observed.

Atmospheric trace elements in Alpine snow

P. Gabrielli et al.

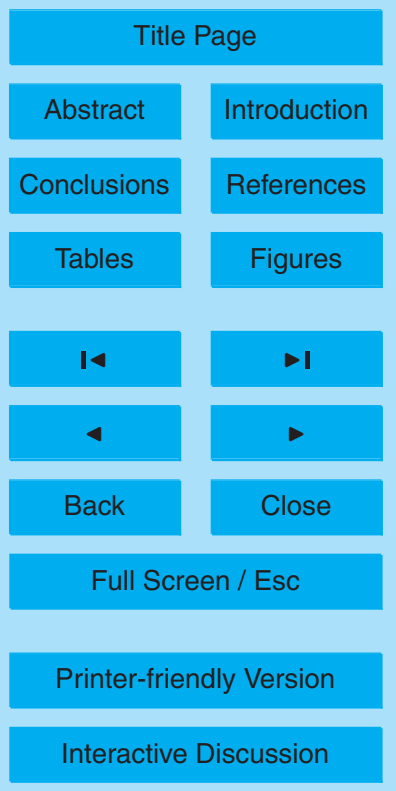




\subsection{Sources assessment of the contaminants}

\subsubsection{The statistical method}

To evaluate the origin of the trace elements determined in the snow of the Eastern Alps, a principal component analysis (PCA) (Stanimirova et al., 2005) was carried out 5 in order to reveal linear relations existing in the chemical data set.

The large range covered by the concentrations values ( 6 orders of magnitude), the lognormal like distributions of the chemical variables and the frequent occurrence of several outliers, highlighted the need to adopt a data set transformation before applying the PCA. This consisted of the substitution of the chemical concentration with its rank position (Baxter, 1995). This yielded several advantages: firstly, ranking avoids the data set being constrained by the unity of measure that could produce a virtual variability, secondly a PCA based on ranks can be expected to be more robust to outliers (Baxter, 1995) and thirdly this transformation accentuates the essential variability of the data set, by ignoring the secondary variability (background noise) (Molinaroli et al., 1999).

15 Coherent with the ranking, is the substitution (before the rank transformation) of missing data with the median, a robust parameter depending only on the rank position (Thomson, 1993). PCA was adopted by applying the varimax rotation. In order to represent at least one variable, the minimum acceptable variance (eigenvalue) of the principal components selected for the following discussion was 1 . In addition, a variable 20 was considered significant and representative for this statistical description when the fraction of its explained variance (communality) obtained at least the value of 0.50 .

\subsubsection{Results of the PCA}

PCA applied on the entire chemical data set put in evidence three principal components, summarising the information contained in 22 chemical variables on the 23 available. $\mathrm{K}^{+}$resulted in fact as not significant when compared to the above fixed criteria. Variance distribution of the first three principal components and the scores of the chem-

\section{Atmospheric trace elements in Alpine snow}

P. Gabrielli et al.

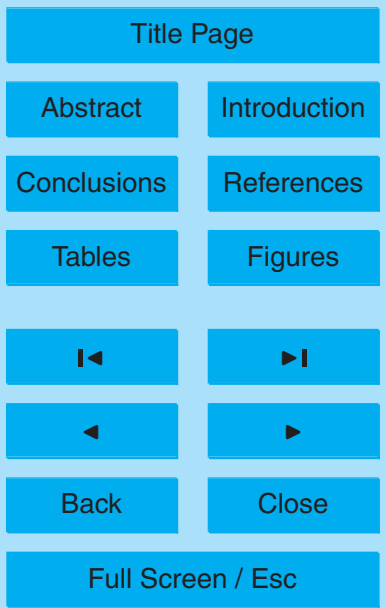

Printer-friendly Version

Interactive Discussion 
ical variables are reported in Tables 5 and 6 respectively. It is remarkable to mention that the application of PCA to sub groups of selected samples such as those coming from high/low altitude sampling sites, fresh/old snow samples, remote/rural sampling sites did not produce substantially different results from those reported below for the 5 PCA applied to the entire data chemical set (Gabrielli, 1998).

Trace elements (Ag, Ba, Bi, Cd, Co, Cr, Cu, Fe, Mo, Mn, Pb, Sb, Ti, U, V and Zn) obtained high scores on the first principal component, $\mathrm{Cl}^{-}, \mathrm{Na}^{+}, \mathrm{SO}_{4}^{2-}$ and $\mathrm{NO}_{3}^{-}$on the second, $\mathrm{Mg}^{2+}$ and $\mathrm{Ca}^{2+}$ on the third. It should be noted that some trace elements such as $\mathrm{Ti}, \mathrm{U}, \mathrm{Mn}, \mathrm{Fe}, \mathrm{Ba}$ and to a lesser extent $\mathrm{Cu}, \mathrm{Co}$ and $\mathrm{Cr}$ obtained rather high 10 scores also on the third principal component governed by $\mathrm{Mg}^{2+}$ and $\mathrm{Ca}^{2+}$. On the other hand, another group of metals, composed of $\mathrm{V}, \mathrm{Sb}, \mathrm{Zn}, \mathrm{Cd}$, Mo, Pb obtained significant scores also on the second principal component governed by $\mathrm{SO}_{4}^{2-}, \mathrm{NO}_{3}^{-} \mathrm{Cl}^{-}$, $\mathrm{Na}^{+}$. This is visually emphasized, by applying a cluster analysis on the principal component score matrix (Fig. 3), adopting the Euclidean distance and the Ward method for 15 group aggregation (Swan Sandilands, 1995). Trace elements are into two sub-groups composed of Ti, U, Mn, Fe, Ba, Cu, Co, Cr on one side and V, Sb, Zn, Cd, Mo, Pb, Ag and $\mathrm{Bi}$ on the other. In addition, the cluster analysis disaggregates distinctly also the second principal component in two sub-groups composed of $\mathrm{SO}_{4}^{2-}$ and $\mathrm{NO}_{3}^{-}$on one side and $\mathrm{Na}^{+}$and $\mathrm{Cl}^{-}$on the other.

\subsubsection{Sources analysis}

\section{The crustal contribution}

An explanation of the trace elements disaggregation into two distinct clusters can be obtained by comparing the trace elements concentrations in the snow with the average trace element concentration determined in the carbonates (Taylor McLennan, 1985), that constitute the geological background of the Dolomites. The $\mathrm{Ca}^{2+}$ contribution from remote crustal sources can be considered negligible since no significant

Atmospheric trace elements in Alpine snow

P. Gabrielli et al.

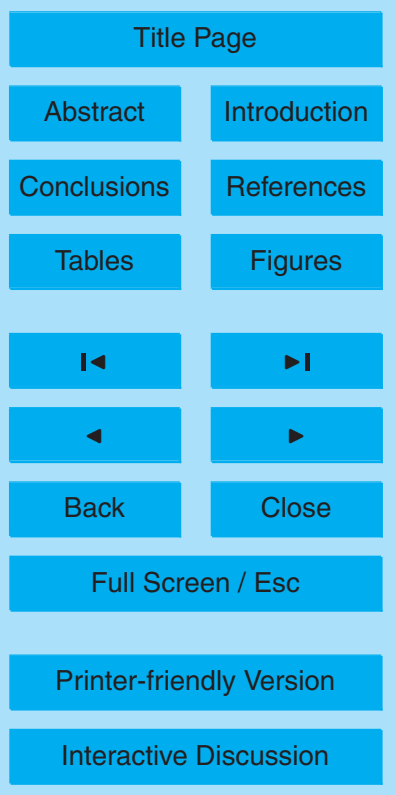

EGU 
transport of Saharan dust to the Alps occurred during the winter of 1998. This type of transport is in fact usually not occurring in the Alps during the cold season (De Angelis Gaudichet, 1991). $\mathrm{Ca}^{2+}$ can thus be adopted as the most characteristic crustal species over the examined territory. The prevalent regional origin of $\mathrm{Ca}^{2+}$ (but 5 also of $\mathrm{Mg}^{2+}$ ) is confirmed considering that its average concentrations in the sampling sites, mostly characterised by a granitic and metamorphic background such as Malga Bissina (226 ppb), Presena Summit (88 ppb) and Mount Vioz (149ppb), are mainly lower than elsewhere ( 300-600 ppb), where, in contrast, carbonates dominate.

For a given trace element, Mn for instance, the percentage of the carbonates contri10 bution to its budget can be calculated as

$\left.\left[\left((\mathrm{Mn})_{r} /\left(\mathrm{Ca}^{2+}\right)_{r}\right) /(\mathrm{Mn})_{s} /\left(\mathrm{Ca}^{2+}\right)_{s}\right)\right] \times 100$

where, $(\mathrm{Mn})_{s}$ and $\left(\mathrm{Ca}^{2+}\right)_{s}$ represent the concentration in the snow sample and $(\mathrm{Mn})_{r}$ and $\left(\mathrm{Ca}^{2+}\right)_{r}$ the average concentration in the carbonates (Taylor McLennan, 1985). The carbonates average contribution resulted as high for $\mathrm{Mn}(100 \%), \mathrm{U}(91 \%), \mathrm{Ti}$ 15 (65\%), Fe (50\%), Cr (32\%), V (24\%), whereas for Ag, Cd, Co, Sb, Mo, Cu, Pb, Ba and $\mathrm{Zn}$ it was less than $3 \%$. Thus we can conclude that trace elements such as $\mathrm{Ti}$, $\mathrm{U}, \mathrm{Mn}$ and Fe obtained rather high scores on the third principal component governed by $\mathrm{Ca}^{2+}$ and $\mathrm{Mg}^{2+}$ because they were most likely originating from the Alpine geological background and in particular from the Dolomites. However, a concurrent secondary crustal contribution from different geological backgrounds, such as granitic and metamorphic rocks, which are particularly diffuse in the western part of the examined territory (and more in general in the entire Alpine chain), is likely not only for $\mathrm{Ti}, \mathrm{U}, \mathrm{Mn}, \mathrm{Fe}$ but especially for $\mathrm{Cr}, \mathrm{Co}, \mathrm{Cu}$ and $\mathrm{Ba}$. These latter elements showed in fact a crustal behaviour linked to their association with $\mathrm{Ti}, \mathrm{U}, \mathrm{Mn}$, Fe but had rather low or negligible carbonate contributions.

An important rock and soil dust contribution for $\mathrm{Cu}, \mathrm{Mn}, \mathrm{Ti}, \mathrm{Fe}, \mathrm{Ba}$, $\mathrm{Co}$ and $\mathrm{U}$ was found in Alpine ice and snow also from Van de Velde and Veysseire and co-workers (Van de Velde et al., 1998; Veysseyre et al., 2001). Interestingly, U on the Eastern

Atmospheric trace elements in Alpine snow

P. Gabrielli et al.

Title Page
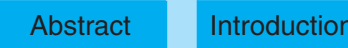

Conclusions

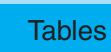

References

Tables

Figures

14

4

Back

Full Screen / Esc

Printer-friendly Version

Interactive Discussion 
Alps was not found to show an excess above the crustal contribution, in contrast with the excesses recently reported for $U$ determined in Mont Blanc snow and ice, which was attributed to extensive mining activity in former Eastern Germany (GDR) during the '80s (Barbante et al., 2001a).

5

\section{The marine contribution}

The excellent linkage between $\mathrm{Na}^{+}$and $\mathrm{Cl}^{-}$, concurrently with the mean mass concentration ratio $\mathrm{Cl}^{-} / \mathrm{Na}^{+}$of 2.5 (not far from the marine ratio of 1.8; the slight $\mathrm{Cl}^{-}$ 10 excess in our samples could be attributed to a minor anthropogenic contribution of HCl; Puxbaum, 1991; Nickus et al., 1997; Winiwarter et al., 1998), clearly shows a prevalent marine input for these two major ions. This is likely due to the close proximity of the Mediterranean sea and the Adriatic sea in particular, since there is an apparent spatial concentration gradient (also shown previously by Della Lucia and co-workers; Della Lucia et al., 1996) amongst the more sea exposed sampling sites in the Pre-Alps (for $\mathrm{Na}^{+}$, Mount Tomba (170 ppb), Mount Grappa (330 ppb), Faverghera (138 ppb)) and the more internal snow fields in the north western part of Trentino (for $\mathrm{Na}^{+}$, Mount Presena (47 ppb), Mount Vioz (43 ppb), Malga Bissina (53 ppb)).

A prevalent marine origin for $\mathrm{SO}_{4}^{2-}$ can be ruled out because the non sea saltsulphate average contribution is $\sim 90 \%$. This calculation was carried out by considering the nss-sulphate concentration as

$\left(\mathrm{SO}_{4}^{2-}\right)_{\mathrm{nss}}=\left(\mathrm{SO}_{4}^{2-}\right)_{s}-\left(\mathrm{Cl}^{-}\right)_{s}\left(\mathrm{SO}_{4}^{2-}\right)_{m} /\left(\mathrm{Cl}^{-}\right)_{m}$,

where $\mathrm{Cl}^{-}$is considered as the marine reference (the calculation performed with $\mathrm{Na}^{+}$gives essentially the same result), $\left(\mathrm{SO}_{4}^{2-}\right)_{S}$ and $\left(\mathrm{Cl}^{-}\right)_{S}$ are concentrations in the 25 snow and $\left(\mathrm{SO}_{4}^{2-}\right)_{m} /\left(\mathrm{Cl}^{-}\right)_{m}$ is the mean concentration ratio in the sea. The marine contribution to the budget of trace elements determined in the Eastern Alps snow was found also always negligible.

Atmospheric trace elements in Alpine snow

P. Gabrielli et al.

Title Page

Abstract

Introduction

Conclusions

References

Tables

Figures

14

4

Back

Full Screen / Esc

Printer-friendly Version

Interactive Discussion 
The linkage between $\mathrm{SO}_{4}^{2-}$ and $\mathrm{NO}_{3}^{-}$suggests an anthropogenic origin for these two major ions and this study also demonstrates this well known anthropogenic acid 5 factor $\left(\mathrm{SO}_{4}^{2-}\right.$ and $\mathrm{NO}_{3}^{-}$) (Maupetit et al., 1995; Schwikowski et al., 1999; Preunkert et al., 2001). The emissions of their original compounds $\left(\mathrm{NO}_{\mathrm{x}}\right.$ and $\left.\mathrm{SO}_{2}\right)$ are in fact greatly predominant when compared to their corresponding natural sources. $\mathrm{SO}_{4}^{2-}$ and $\mathrm{NO}_{3}^{-}$ average concentrations in snow were found generally higher in the Pre-Alpine sites, which are next to the heavily anthropized Po Valley $\left(\mathrm{NO}_{3}^{-}\right.$in Faverghera (1288 ppb), 10 Mount Grappa (1371 ppb) and Mount Tomba (1047 ppb)), when compared to other less exposed internal sites $\left(\mathrm{NO}_{3}^{-}\right.$on Mount Vioz (743 ppb), Prarodont (752 ppb) and Viote $(888 \mathrm{ppb}))$ in the western part of the territory examined. Similar north-south spatial gradients were previously reported by Nickus and co-workers for $\mathrm{SO}_{4}^{2-}$ (Nickus et al., 1998) and from Balestrini and co-workers (Balestrini et al., 2000). Interestingly, 15 the $\mathrm{NO}_{3}^{-} / \mathrm{SO}_{4}^{2-}$ ratio is very often higher than 1 , as already previously reported in the Eastern Alps (Nickus et al., 1997). This can be ascribed to the fact that air masses coming from the Po Valley contain higher concentrations of $\mathrm{NO}_{2}$ compared to $\mathrm{SO}_{2}$ because of the large use of methane in domestic heating, which enriches the air in $\mathrm{NO}_{2}$ (Camuffo et al., 1991). In addition, in Trentino, emissions of $\mathrm{NO}_{\mathrm{x}}$ $20 \quad\left(15000 \mathrm{~kg} \mathrm{y}^{-1}\right)$ mainly due to road transport are much higher than emissions of $\mathrm{SO}_{\mathrm{x}}$ $\left(1000 \mathrm{~kg} \mathrm{y}^{-1}\right)$ that are mainly due to agriculture and industry (Provincia di Trento, 1998).

\section{The trace element anthropogenic contribution}

${ }_{25} \mathrm{~V}, \mathrm{Sb}, \mathrm{Zn}, \mathrm{Cd}, \mathrm{Mo}, \mathrm{Pb}, \mathrm{Ag}$ and $\mathrm{Bi}$ cannot be linked to a regional geological background because they have a low or negligible carbonate contribution and very low scores on the third principal component, governed by the crustal variables. With the exception of $\mathrm{Ag}$ and $\mathrm{Bi}$, this group of trace metals obtains rather significant scores on the second principal component, showing a relationship with its governing variables,

\section{Atmospheric trace elements in Alpine snow}

P. Gabrielli et al.

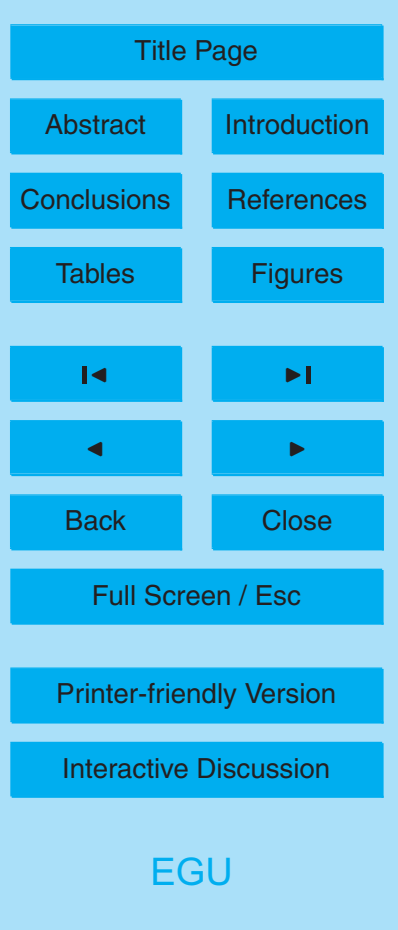


represented by the anthropogenic acid factor $\left(\mathrm{SO}_{4}^{2-}\right.$ and $\left.\mathrm{NO}_{3}^{-}\right)($Maupetit et al., 1995; Schwikowski et al., 1999; Preunkert et al., 2001) and the marine component $\left(\mathrm{Na}^{+}\right.$and $\mathrm{Cl}^{-}$).

Among these trace elements, $\mathrm{Pb}$ and $\mathrm{Cd}$ can be associated to anthropogenic emis5 sions, as concluded from other Alpine snow and ice studies (Van de Velde et al., 1998; Barbante et al., 2004; Schwikowski et al., 2004), because their contribution from anthropogenic sources is greatly prevalent over natural sources (Nriagu Pacyna, 1988; Pacyna, 2001). Just to give an example, in Italy in 1992, $\mathrm{Pb}$ was emitted mostly by road transport traffic $\left(\sim 2000 \mathrm{ty}^{-1}\right)$ and industrial activities $\left(\sim 1000 \mathrm{ty}^{-1}\right)$, and Cd by 10 refuse incineration/electric power plants $\left(\sim 20 \mathrm{ty}^{-1}\right)$, industrial activities $\left(\sim 15 \mathrm{ty}^{-1}\right)$ and road transport traffic $\left(\sim 15 \mathrm{ty}^{-1}\right)$, whereas natural emissions where negligible; Techne, 1998). In particular the intensive automobile and truck traffic in the alpine valleys was likely responsible for the emission of $\mathrm{Pb}$ and $\mathrm{Cd}$ in the considered territory. For instance in Trentino, these sources were responsible in 1995 of the emission of remark5 able quantities of $\mathrm{Cd}\left(\sim 0.25 \mathrm{ty}^{-1}\right)$ and $\mathrm{Pb}\left(\sim 40 \mathrm{ty}^{-1}\right)$ (Provincia di Trento, 1998). In addition, significant contributions of $\mathrm{Pb}$ and $\mathrm{Cd}$ could have originated from the electrometallurgical and electrochemical industries present in the Po Valley.

The linkage with two typically anthropogenic trace elements such as $\mathrm{Pb}$ and $\mathrm{Cd}$ together with the association with the anthropogenic acid factor $\left(\mathrm{SO}_{4}^{2-}\right.$ and $\left.\mathrm{NO}_{3}^{-}\right)$and the negligible carbonate contribution, leads us to consider as anthropogenic other trace element determined in our snow samples and emitted by different activities (in parentheses) such as Mo and Sb (coal and oil combustion in power plants), Ag (waste incineration plants), $\mathrm{Zn}$ (refuse incineration, nonferrous metal and steel production) and $\mathrm{V}$ (thermal power plants and industrial, commercial and residential use of fuel).

25 The significant relationship evidenced by the second principal component (see Table 6) between the anthropogenic acid factor $\left(\mathrm{SO}_{4}^{2-}, \mathrm{NO}_{3}^{-}\right)$(Maupetit et al., 1995), and the anthropogenic trace element contribution ( $\mathrm{V}, \mathrm{Sb}, \mathrm{Zn}, \mathrm{Cd}, \mathrm{Mo}, \mathrm{Pb})$ but also, unexpectedly, with the marine component $\left(\mathrm{Na}^{+}, \mathrm{Cl}^{-}\right)$can be tentatively explained with a common transport trajectory that was taken by the air masses from the Adriatic basin

\section{Atmospheric trace elements in Alpine snow}

P. Gabrielli et al.

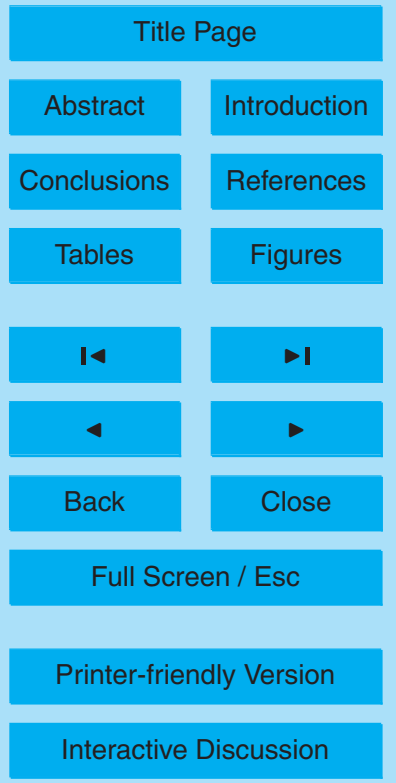


to the Alpine sites through the Po Valley (Seibert et al., 1998). These air masses probably had an initially prevalent marine signature and, due to their passage above the Po Valley, they became polluted by anthropogenic contaminants such as $\mathrm{SO}_{4}^{2-}, \mathrm{NO}_{3}^{-}, \mathrm{V}$, $\mathrm{Sb}, \mathrm{Zn}, \mathrm{Cd}, \mathrm{Mo}$, and $\mathrm{Pb}$. This tentative explanation is supported by the high occurrence

5 of southern winds observed during the winter of 1998. In general the second principal component might thus show a southern provenance for ionic species such as $\mathrm{Na}^{+}, \mathrm{Cl}^{-}$, $\mathrm{SO}_{4}^{2-}, \mathrm{NO}_{3}$ and the anthropogenic trace elements.

\subsection{Meteorological data and transport processes}

Chemical data, determined from our samples with the frequency of a week, were coupled to the continuous meteorological data set, by calculating for every meteorological data point a mean time period from the snowfall day until the sampling day. The PCA applied to the entire chemical and meteorological data set evidenced a clear separation between chemical and meteorological parameters. This could be due to the fact that strictly local meteorological parameters are independent from wet and dry deposition phenomena characterized by a larger spatial scale. This could also mean that the descriptive linear statistics used (PCA) and/or the frequency of sampling was not suitable to evidence possible non-linear relationships between the meteorological and wet/dry deposition phenomena.

However, the evidenced independence of the chemical variables from large-scale 20 transport parameters, such as the wind direction in the free troposphere, is also consistent with the kind of transport characterized by convective turbulences that diffuse local and regional contaminants within the boundary layer. During the winter of 1998, particularly high temperatures were recorded at soil level and in the free troposphere (isotherm of $0^{\circ} \mathrm{C}$ at $3000 \mathrm{~m}$ during the first half of February, for instance). This may 25 have produced a frequent enhancement of the upper limit of the winter boundary layer. Eastern Alps sampling sites, located between $1000 \mathrm{~m}$ and $3000 \mathrm{~m}$, were therefore probably within the boundary layer and were often exposed to the deposition of local and regional contaminants.

\section{Atmospheric trace elements in Alpine snow}

P. Gabrielli et al.

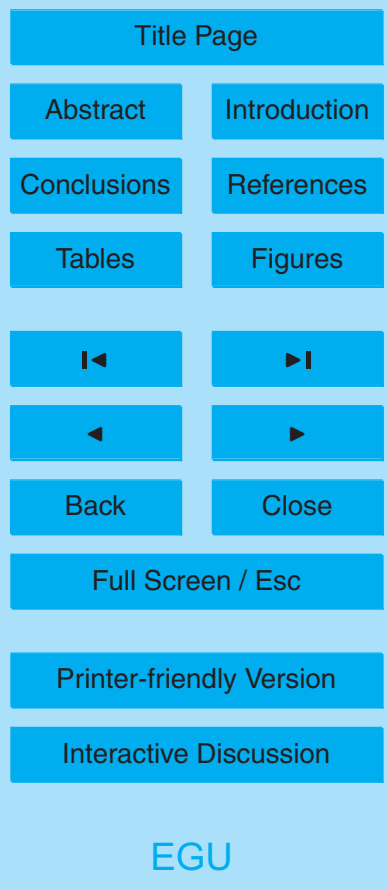


In any case, it seems unlikely that the weak convection originating from the low temperature gradient was the unique cause of the transport of contaminated air masses from the lower to the upper tropospheric levels. During the sampling period, the Alpine troposphere had very often conditions of neutral stability up to $3000 \mathrm{~m}$ (with a gradi5 ent of $6^{\circ} \mathrm{C} / \mathrm{km}$ in average). Orographic induced vertical transport, originating from the action of the synoptic wind, was probably responsible for a more efficient vertical air mixing. Air masses impacting frequently on the southern slope of the Alps might have in fact transported contaminants from the Po Valley to the more exposed slopes of the Pre-Alps. In addition, turbulences generated by the synoptic wind within the more inter10 nal Alpine valleys, might have assisted in mixing contaminants at different levels. This interpretation is coherent with the suggestions of Seibert and co-workers that defined as "sub-grid vertical transport" these modalities of advection not included in their model (Seibert et al., 1998).

\section{Conclusions}

15 We found that trace element content and structure of the winter snow of the Eastern Alps is complex because of the superimposition of several contributions from different sources. The crustal component is represented mainly by $\mathrm{Ca}^{2+}$ and $\mathrm{Mg}^{2+}$ originating from the carbonates background of the Eastern Alps (Dolomites) and from trace elements such as $\mathrm{Mn}, \mathrm{U}, \mathrm{Ti}, \mathrm{Fe}$ and to a lesser extent $\mathrm{Cr}, \mathrm{Co}, \mathrm{Cu}$ and $\mathrm{Ba}$. The marine 20 component as represented by $\mathrm{Na}^{+}$and $\mathrm{Cl}^{-}$, probably originated from the nearby Adriatic basin. The anthropogenic contribution is represented by trace metals such as $\mathrm{V}$, $\mathrm{Sb}, \mathrm{Zn}, \mathrm{Cd}, \mathrm{Mo}, \mathrm{Pb}, \mathrm{Ag}, \mathrm{Bi}$ and by the major ions $\mathrm{SO}_{4}^{2-}$ and $\mathrm{NO}_{3}^{-}$representing the anthropogenic acid factor. Considering the winter structure of the low Alpine troposphere, the anthropogenic contaminants entrapped within the boundary layer, have probably a local and a regional origin. Our data suggests that the very industrialised Po Valley can affect especially the more exposed Southern Pre-Alpine slopes. The influence on the chemical snow composition of other very diffuse sources of emission (roads, tourist

\section{Atmospheric trace elements in Alpine snow}

P. Gabrielli et al.

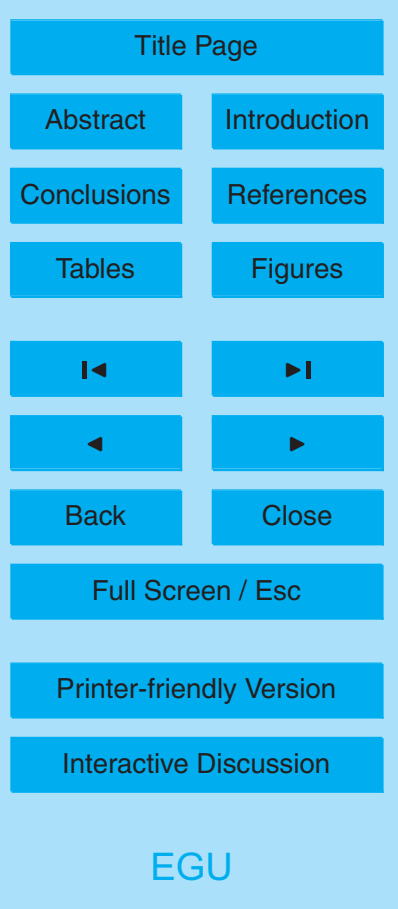


stations, villages) in the internal alpine valleys is also very likely. The mechanism of transport of contaminants from low altitude to the snow of the Alpine fields could be due, in addition to the weak convective turbulence inside the winter boundary layer, as well as the vertical transport and turbulences generated by the synoptic wind.

5 Acknowledgements. This project was carried out in collaboration with the Snow Avalanches and Meteorology Office of the Trento Province, the Environmental Protection Agency of the Trento Province, the Experimental Centre For Avalanches and Idrogeology Defence of the Environmental Protection Agency of Veneto Region. The authors are thankful for the technical and scientific support in particular from G. Tecilla, M. Mazzola, G. Tognoni, P. Cestari and M. Tava 10 (Trento Province), A. Luchetta, M. Valt, T. Corso and A. Cagnati (Veneto Region) and for the precious help in data elaboration with G. Rampazzo (University Ca'Foscari of Venice). W. Cairns (IDPA) is acknowledged for useful discussions. The financial support of Istituto Nazionale della Montagna (IMONT) is kindly acknowledged.

\section{References}

Alley, R. B., Finkel, R. C., Nishiizumi, K., Anandakrishnan, S., Shuman, C. A., Mershon, G., Zielinski, G. A., and Mayewski, P. A.: Changes in continental and sea-salt atmospheric loadings in central Greenland during the most recent deglaciation: model-based estimates, J. Glaciol., 41, 503-514, 1995

Balestrini, R., Galli, L., and Tartari, G.: Wet and dry atmospheric deposition at prealpine and alpine sites in northern Italy, Atmos. Environ., 34, 1455-1470, 2000

Barbante, C., Bellomi, T., Mezzadri, G., Cescon, P., Scarponi, G., Morel, C., Jay, S., Van de Velde, K., Ferrari, C., and Boutron, C. F.: Direct determination of heavy metals at pico gram per gram level in Greenland and Antarctic snow by Double Focusing Inductively Coupled Plasma Mass Spectrometry, J. Anal. At. Spectrom., 12, 925-931, 1997

Barbante, C., Boutron, C. F., Moreau, A. L., Ferrari, C., Van de Velde, K., Cozzi, G., Turetta, C., and Cescon, P.: Sasonal variations in nickel and vanadium in Mont Blanc snow and ice dated from the 1960 and 1990s, J. Environ. Monit., 4, 960-966, 2002

Barbante, C., Boutron, C. F., Morel, C., Ferrari, C., Jaffrezo, J. L., Cozzi, G., Gaspari, V., and

\section{Atmospheric trace elements in Alpine snow}

P. Gabrielli et al.

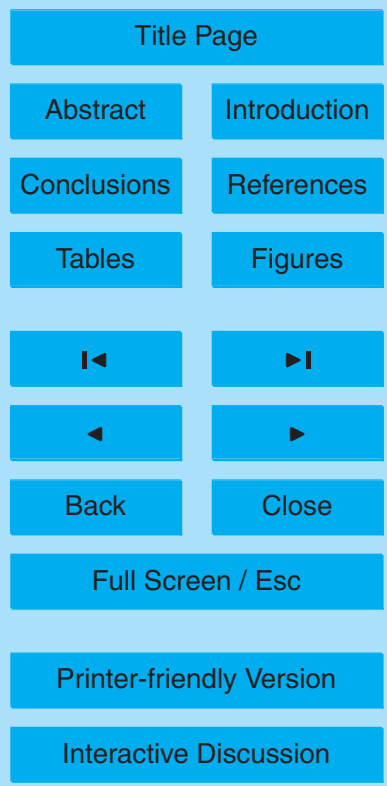


Cescon, P.: Seasonal variations of heavy metals in central Greenland snow deposited from 1991 to 1995, J. Environ. Monit., 5, 328-335, 2003

Barbante, C., Cozzi, G., Capodaglio, G., Van de Velde, K., Ferrari, C., Boutron, C. F., and Cescon, P.: Trace element determination in alpine snow and ice by double focusing induc5 tively coupled plasma mass spectrometry with microcentric nebulization, J. Anal. At. Spectrom., 14, 1433-1438, 1999.

Barbante, C., Schwikowski, M., Doring, T., Gaggeler, H. W., Shottered, U., Tobler, L., Van de Velde, K., Ferrari, C., Cozzi, G., Turetta, A., Rosman, K., Bolshov, M. A., Capodaglio, G., Cescon, P., and Boutron, C. F.: Historical Record of European Emission of Heavy Metals to the Atmosphere Since the 1650s from Alpine Snow/lce cores Drilled near Monte Rosa, Environ. Sci. Technol., 38, 4085-4090, 2004

Barbante, C., Van de Velde, K., Cozzi, G., Capodaglio, G., Planchon, F., Hong, S., Ferrari, C., and Boutron, C. F.: Post-World War II Uranium Changes in Dated Mont Blanc Ice and Snow, Environ. Sci. Technol., 35, 4026-4030, 2001a

Barbante, C., Veysseyre, A., Ferrari, C., Van de Velde, K., Morel, C., Capodaglio, G., Cescon, P., Scarponi, G., and Boutron, C. F.: Greenland snow evidence of large scale atmospheric contamination from platinum, palladium and rhodium, Environ. Sci. Technol., 35, 835-839, 2001b

Baxter, M. J.: Standardization and Trasformation in Principal Component Analysis, with Applications to Archaeometry, App. Stat., 44, 513-527, 1995

Boutron, C. F.: A clean laboratory for ultralow concentration heavy metal analysis, Fresenius J. Anal. Chem., 337, 482-491, 1990

Cadle, S. H.: Dry deposition to snowpack. Seasonal snowpacks, in: series, edited by: Davis, T. D., Tranter, M., Jones, H. G., NATO ASI series, 28, Springer Verlag, Berlin, 1991.

Camuffo, D., Bernardi, A., and Bacci, P.: Transboundary transport of atmospheric pollutants through the eastern alps, Atmos. Environ., 25, 2863-2871, 1991

Correia, A., Freydier, R., Delmas, R. F., Simoes, J. C., Taupin, J. D., Dupré, B., and Artaxo, P.: Trace elements in South America aerosol during 20th century inferred from a Nevado Illimani ice core, Eastern Bolivian Andes (6350 m a.s.l.), Atmos. Chem. Phys., 3, 1337-1352, 2003

30 Davidson, C. I.: Mechanism of wet and dry deposition of atmsopheric contaminants to snow surfaces, in: The environmental record in glacier and ice sheets, edited by: Wiley, J., New York, 1989.

Davis, R. E.: Links between snowpack physics and snowpack chemistry, in: Processes of

Atmospheric trace elements in Alpine snow

P. Gabrielli et al.

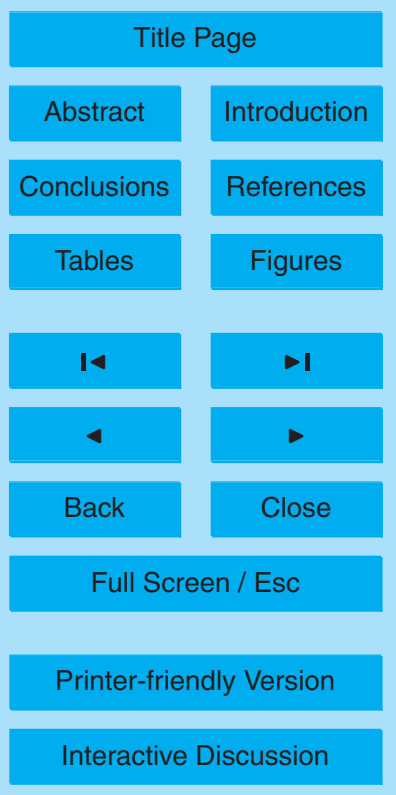


Chemical Change in Snowpacks, Springer-Verlag, edited by: Davies, T. D., Tranter, M., and Jones, H. G., Berlin, 115-139, 1991.

De Angelis, M. and Gaudichet, A.: Saharan dust deposition over Mont Blanc (French Alps) during the last 30 years, Tellus, 34B, 61-75, 1991

5 Della Lucia, M., Marchetto, A., Mosello, R., and Tartari, G.: Studies on a chemical gradient of atmospheric deposition from the Po Valley to the Alps, Water Air Soil Pollut., 87, 171-187, 1996

Ferrari, C. P., Clotteau, T., Thompson, L. G., Barbante, C., Cozzi, G., Cescon, P., Hong, S., Maurice-Bourgoin, L., Francou, B., and Boutron, C. F.: Heavy metals in ancient tropical ice:

10 initial results, Atmos. Environ., 35, 5809, 2001

Fuzzi, S.: Clouds in the troposphere, in: Topics in atmospheric and interstellar physics and chemistry, edited by: Boutron, C. F., Les Editions de physique, Les Ulis, 1994.

Gabrielli, P.: Elementi in traccia nelle precipitazioni nevose delle Alpi Orientali: origine, evoluzione stagionale e relazione con le condizioni meteorologiche, Tesi di laurea, University of Venice, 1998.

Gabrielli, P., Barbante, C., Boutron, C. F., Cozzi, G., Gaspari, V., Planchon, F., Ferrari, C., and Cescon, P.: Variations in atmospheric trace elements in Dome $C$ (East Antarctica) ice over the last two climatic cycles, Atmos. Environ., 39, 6420-6429, 2005.

Gabrielli, P., Barbante, C., Plane, J. M. C., Varga, A., Hong, S., Cozzi, G., Gaspari, V., Planchon, F., Cairns, W., Ferrari, C., Crutzen, P., Cescon, P., and Boutron, C. F.: Meteoric smoke fallout over the Holocene epoch revealed by iridium and platinum in Greenland ice, Nature, 432, 1011-1014, 2004.

Gaspari, V., Barbante, C., Cozzi, G., Cescon, P., Boutron, C. F., Gabrielli, P., Capodaglio, G., Ferrari, C., Petit, J. R., and Delmonte, B.: Atmospheric iron over the last deglaciation: Climatic implications, Geophys. Res. Lett., 33, L03704, doi:10.1029/2005GL024352, 2006.

Gauchard, P. A., Aspmo, K., Temme, C., Steffen, A., Ferrari, C., Berg, T., Planchon, F., Dommergue, A., Bahlmann, E., Magand, O., Ebinghaus, R., Banic, C., Storm, J., Barbante, C., Boutron, C. F., and Baussand, P.: An international study of Mercury, Ny-Ålesund spring 2003: Characterizing atmospheric mercury depletion events, Atmos. Environ., 39, 76207632, 2004.

Gerdol, R. and Bragazza, L.: Effects of altitude on element accumulation in alpine moss, Chemosphere, 64, 810-816, 2006.

Gragnani, R., Smiraglia, C., Stenni, B., and Torcini, S.: Chemical and isotopic profiles from

Atmospheric trace elements in Alpine snow

P. Gabrielli et al.

Title Page

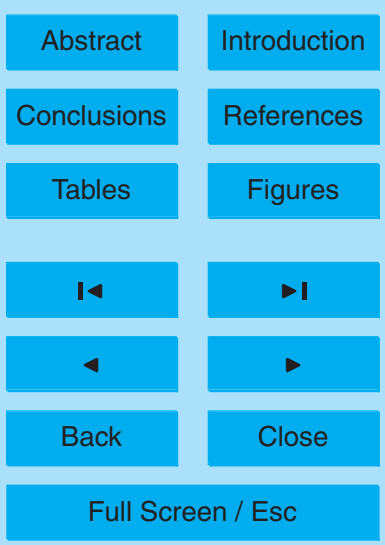

Printer-friendly Version

Interactive Discussion 
snow pits and shallow firn cores on Campbell Glacier (Northern Victoria Land, Antarctica, Ann. Glaciol., 27, 679-684, 1998.

Hong, S., Barbante, C., Boutron, C. F., Gabrielli, P., Gaspari, V., Cescon, P., Thomson, D. S., Ferrari, C., Francou, B., and Bourgoin, M.: Atmospheric heavy metals in tropical South 5 America during the past 22000 years recorded in a high altitude ice core from Sajama, Bolivia, Jour. Env. Monitor., 6, 222-226, 2004.

Hong, S., Candelone, J. P., Patterson, C. C., and Boutron, C. F.: History of ancient copper smelting pollution during Roman and medieval times recorded in Greenland ice, Science, 272, 246-249, 1996.

10 Kappeberger, G. and Kerkmann, J., II tempo in montagna, manuale di meteorologia alpina, Zanichelli, Milano, 1997.

Krachler, M., Zheng, J., Koerner, R. M., Zdanowicz, C., Fisher, D. A., and Shotyk, W.: Increasing atmospheric antimony contamination in the northern hemisphere: snow and ice evidence from Devon Island, Arctic Canada, J. Environ. Monit., 7, 2005.

Latini, A.: Analisi della distribuzione delle precipitazioni nevose sulle Alpi italiane in relazione ai tipi di tempo e alle correnti in quota, Rivista di meteorologia areonautica, 47, 198, 1987.

Maupetit, F., Wagenbach, D., Weddeling, P., and Delmas, R. F.: Seasonal fluxes of major ions to high altitude cold alpine glacier, Atmos. Environ., 29, 1-9, 1995

Molinaroli, E., Pistolato, M., Rampazzo, G., and Guerzoni, S.: Geochemistry of natural and anthropogenic fallout (aerosol and precipitation) collected from the NW Mediterranean: two different multivariate statistical approaches, App. Geochem., 14, 423-432, 1999.

Nickus, U., Kuhn, M., Baltensperger, U., Delmas, R. F., Gaeggeler, H. W., Kasper, A., KrompKolb, H., Maupetit, F., Novo, A., Pichlmayer, F., Preunkert, S., Puxbaum, H., Rossi, G. C., Schoner, W., Schwikowski, M., Seibert, P., Staudinger, M., Trockner, V., Wagenbach, D., and Winiwarter, W.: SNOSP: Ion deposition and concentration in high alpine snow packs, Tellus, 49B, 56-71, 1997.

Nickus, U., Kuhn, M., Novo, A., and Rossi, G. C.: Major element chemistry in Alpine snow along a North-South transect in the Eastern Alps, Atmos. Environ., 32, 4053-4060, 1998

Nriagu, J. O. and Pacyna, J. M.: Quantitative assessment of world-wide contamination of air, water and soils by trace metals, Nature, 333, 134-139, 1988.

Pacyna, J. M. and Pacyna, E. G.: An assessment of global and regional emissions of trace metals to the atmosphere from anthropogenic sources world-wide, Environ. Rev., 9, 269298, 2001.

Atmospheric trace elements in Alpine snow

P. Gabrielli et al.

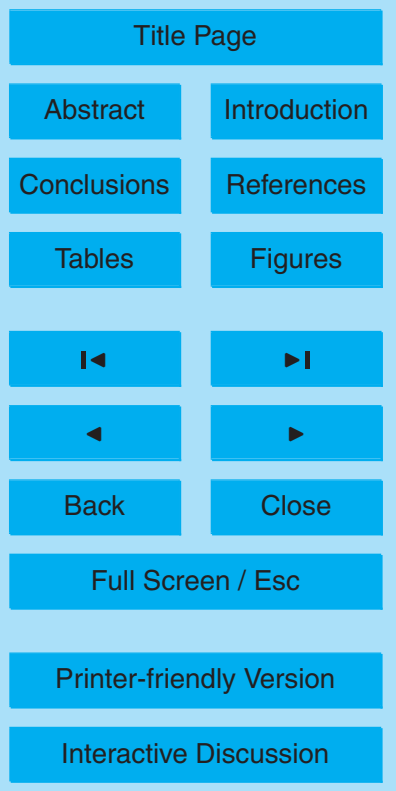


Planchon, F., Boutron, C. F., Barbante, C., Cozzi, G., Gaspari, V., Wolff, E. W., Ferrari, C., and Cescon, P.: Changes in heavy metals in Antarctic snow from Coats Land since the mid-19th to the late-20th century, Earth Planet. Sci. Lett., 200, 207-222, 2002.

Planchon, F., Boutron, C. F., Barbante, C., Wolff, E. W., Cozzi, G., Gaspari, V., Ferrari, C., and Cescon, P.: Ultrasensitive determination of heavy metals at the sub-picogram per gram level in ultraclean Antarctic snow samples by inductively coupled plasma sector field mass spectrometry, Anal. Chim. Acta, 450, 193-205, 2001.

Posch, M., Slootweg, J., and Hettelingh, J. P.: European Critical loads and Dynamic modelling: CCE Status Report 2005, 2005.

10 Preunkert, S., Legrand, M., and Wagenbach, D.: Sulfate trends in a Col du Dome (French Alps) ice core: A record of anthropogenic sulfate levels in the European midtroposphere over the twentieth century, J. Geophys. Res., 106, 31 991-32 004, 2001.

Provincia di Trento, Piano provinciale di risanamento e tutela della qualità dell'aria, in: APPA, (Ed), Provincia di Trento, 1998.

Puxbaum, H.: Chemical composition and fluxes of wet deposition at elevated sites (700$3195 \mathrm{~m}$ a.s.I.) in the Eastern Alps (Austria), in: Seasonal Snowpacks Processes of Compositional Change 28, edited by: Davies, T. D., Tranter, M., and Jones, H. G., Springer-Verlag, Berlin, p. 471, 1991.

Schwikowski, M.: Reconstruction of European air pollution from Alpine ice cores, in: Earth paleoenvironments: Records preserved in Mid and low Latitude Glaciers, edited by: Cecil, L. D., Thompson, L. G., Steig, E. J., and Green, J. R., ,Kluwer Academic/Plenum Publishers, 2003

Schwikowski, M., Barbante, C., Doering, T., Gaeggeler, H. W., Boutron, C. F., Schotterer, U., Tobler, L., Van de Velde, K., Ferrari, C., Cozzi, G., Rosman, K., and Cescon, P.: Post-17Century Changes of European Lead Emissions Recorded in High-Altitude Alpine snow and Ice, Environ. Sci. Technol., 38, 957-964, 2004

Schwikowski, M., Doscher, A., Gaeggeler, H. W., and Shottered, U.: Anthropogenic versus natural sources of atmospheric sulphate from an Alpine ice core, Tellus, 51B, 938-951, 1999

Seibert, P., Kromp-Kolb, H., Kasper, A., Kalina, M., Puxbaum, H., Jost, D. T., Schwikowski, 30 M., and Baltensperger, U.: Transport of polluted boundary layer air from the Po Valley to high-Alpine sites, Atmos. Environ., 32, 3953-3965, 1998

Shotyk, W., Zheng, J., Krachler, M., Zdanowicz, C., Koerner, R. M., and Fischer, D.: Predominance of industrial $\mathrm{Pb}$ in recent snow (1994-2004) and ice (1842-1996) from Devon Island,

\section{Atmospheric trace elements in Alpine snow}

P. Gabrielli et al.

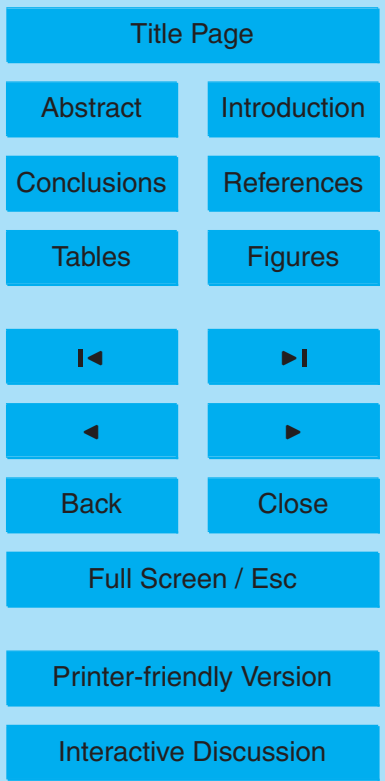


Arctic Canada, Geophys. Res. Lett., 32, L21814, doi:10.1029/GL023860, 2005.

Stanimirova, I., Daszykowski, M., Massart, D. L., Questier, F., Simeonov, V., and Puxbaum, H.: Chemometrical exploration of the wet precipitation chemistry from the Austrian Monitoring Network (1988-1999), Jour. Env. Manag., 74, 349-363, 2005.

5 Swan, A. and Sandilands, M. H.: Introduction to Geological Data analysis, Blackwell Science Ltd., Oxford, 1995.

Taylor S. R. and McLennan, S. M.: The continental crust: its composition and evolution, Blackwell Scientific publications, 1985.

Techne, Statistiche di emissioni, Roma, 1998.

10 Thomson, M.: Efficacy of robust analysis of variance for the interpretation of data from collaborative trials, Analyst, 118, 235-240, 1993

Van de Velde, K., Boutron, C. F., Ferrari, C., Bellomi, T., Barbante, C., Rudnev, S., and Bolshov, M. A.: Seasonal variation of heavy metals in the 1960s Alpine ice: sources versus meteorological factors, Earth Planet. Sci. Lett., 164, 521-533, 1998

Van de Velde, K., Boutron, C. F., Ferrari, C., Moreau, A. L., Delmas, R. F., Barbante, C., Bellomi, T., Capodaglio, G., and Cescon, P.: A two hundred years record of atmospheric Cadmium, Copper and Zinc concentrations in high altitude snow and ice from the French-Italian Alps, Geophys. Res. Lett., 27, 249-252, 2000

Van de Velde, K., Ferrari, C., Barbante, C., Moret, I., Bellomi, T., Hong, S., and Boutron, C. F.: A 200 Year Record of Atmospheric Cobalt, Molybdenum, and Antimony in High Altitude Alpine Firn and Ice, Environ. Sci. Technol., 33, 3495-3501, 1999

Veysseyre, A., Moutard, K., Ferrari, C., Van de Velde, K., Barbante, C., Cozzi, G., Capodaglio, G., and Boutron, C. F.: Heavy metals in fresh snow collected at different altitudes in the Chamonix and Maurienne valleys, French Alps: initial results, Atmos. Environ., 35, 415-425, 2001

Winiwarter, W., Puxbaum, H., Schoner, W., Bohm, R., Werner, A., Vitovec, W., and Kasper, A.: Concentration of ionic compounds in the wintertime deposition: results and trends from the Austrian Alps over 11 years (1983-1993), Atmos. Environ., 32, 4031-4040, 1998

Wolff, E. W. and Suttie, E. D.: Antarctic snow record of Southern Hemisphere lead pollution, Geophys. Res. Lett., 21, 781-784, 1994

Zechmeister, H. G.: Correlation between altitude and heavy metals deposition in the Alps, Environ. Pollut., 89, 73-80, 1995
Atmospheric trace elements in Alpine snow

P. Gabrielli et al.

Title Page

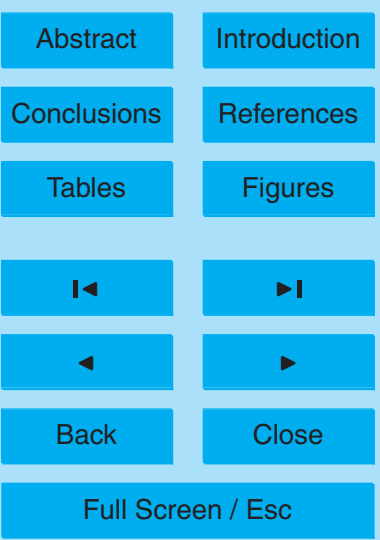

Printer-friendly Version

Interactive Discussion 
Table 1. Sampling sites in Trentino (TN) and in Veneto (Province of Belluno (BL), Province of Vicenza (VI) and Province of Verona (VR)) in the Italian Eastern Alps. Further information can be found in Internet on http://www.meteotrentino.it/AspWeb/Monitoraggi/stations/yeti/Campi_ neve/mappa/mappa_neve.asp and http://www.arpa.veneto.it/csvdi/nivo.htm\\#ubicazione.

\begin{tabular}{llll}
\hline $\mathrm{N}^{\circ}$ & Area & Locality & Altitude $(\mathrm{m})$ \\
\hline 1 & Mount Vioz & Tarlenta (TN) & 2030 \\
2 & Brenta & Prarodont (TN) & 1530 \\
3 & Bondone & Viote (TN) & 1500 \\
4 & Lagorai & Panarotta (TN) & 1875 \\
5 & Ledro & Tremalzo (TN) & 1550 \\
6 & Lagorai & Brocon Pass (TN) & 1550 \\
7 & Adamello & Malga Bissina (TN) & 1780 \\
8 & Primiero & Noana valley (TN) & 1025 \\
9 & Adamello/Presanella & Tonale Pass (TN) & 1880 \\
10 & Presanella & Folgarida (TN) & 1910 \\
11 & Adamello/Presanella & Mount Presena (TN) & 3040 \\
12 & Latemar & Pampeago (TN) & 1900 \\
13 & Comelico & Mount Croce Pass (BL) & 1960 \\
14 & Tofane & Ravales (BL) & 2615 \\
15 & Dolomites & Mounts of Ornella (BL) & 2250 \\
16 & Dolomites & Mount Pradazzo (BL) & 2200 \\
17 & Agner & Gosaldo (BL) & 1350 \\
18 & Pre- Alps & Faverghera (BL) & 1605 \\
19 & Pre-Alps & Mount Grappa (VI) & 1540 \\
20 & Folgaria-Asiago & Campomolon (VI) & 1735 \\
21 & Lessini & Mount Tomba (VR) & 1620 \\
\hline
\end{tabular}

6, 8781-8815, 2006

Atmospheric trace elements in Alpine snow

P. Gabrielli et al.

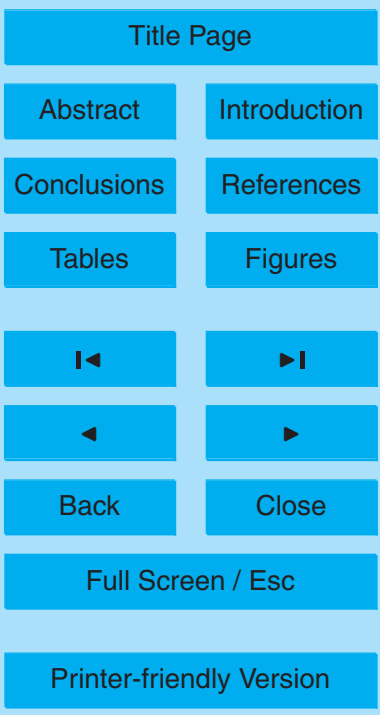

Interactive Discussion 
Table 2. Summary of statistics.

ACPD

6, 8781-8815, 2006

\begin{tabular}{|c|c|c|c|c|c|c|c|c|c|}
\hline & $\mathrm{N}^{\circ}$ & $\begin{array}{l}\text { Mean } \\
(\mathrm{ppb})\end{array}$ & $\begin{array}{l}\text { SD } \\
\text { (ppb) }\end{array}$ & $\begin{array}{l}\text { Median } \\
(\mathrm{ppb})\end{array}$ & $\begin{array}{l}\text { Minimum } \\
(\mathrm{ppb})\end{array}$ & $\begin{array}{l}\text { Maximum } \\
(\mathrm{ppb})\end{array}$ & Max/Min & Skewness & Kurtosis \\
\hline $\mathrm{Ag}$ & 366 & 0.005 & 0.007 & 0.003 & 0.001 & 0.11 & 107 & 9.4 & 117.3 \\
\hline $\mathrm{Ba}$ & 366 & 1.3 & 2.7 & 0.5 & 0.009 & 36.5 & 365 & 7.7 & 85.7 \\
\hline $\mathrm{Bi}$ & 366 & 0.006 & 0.011 & 0.003 & 0.0001 & 0.12 & 116 & 5.9 & 47.5 \\
\hline $\mathrm{Cd}$ & 366 & 0.061 & 0.033 & 0.052 & 0.016 & 0.22 & 14 & 1.7 & 3.5 \\
\hline Co & 366 & 0.048 & 0.084 & 0.025 & 0.002 & 0.97 & 487 & 6.1 & 50.9 \\
\hline $\mathrm{Cr}$ & 366 & 0.10 & 0.21 & 0.045 & 0.003 & 3.0 & 995 & 8.5 & 97.9 \\
\hline $\mathrm{Cu}$ & 366 & 0.72 & 1.86 & 0.28 & 0.008 & 29.1 & 2911 & 11.2 & 157.4 \\
\hline $\mathrm{Fe}$ & 366 & 27.3 & 74.6 & 10.1 & 0.067 & $1.1 \times 10^{3}$ & 10577 & 9.4 & 112.3 \\
\hline $\mathrm{Mn}$ & 366 & 4.3 & 14.0 & 1.2 & 0.001 & 173 & 1731 & 9.1 & 97.3 \\
\hline Mo & 366 & 0.052 & 0.054 & 0.040 & 0.011 & 0.72 & 66 & 6.4 & 66.5 \\
\hline $\mathrm{Pb}$ & 366 & 1.8 & 2.9 & 0.87 & 0.023 & 33.7 & 337 & 5.2 & 44.7 \\
\hline $\mathrm{Sb}$ & 366 & 0.076 & 0.362 & 0.031 & 0.0017 & 6.2 & 3087 & 14.7 & 233.8 \\
\hline $\mathrm{Ti}$ & 366 & 2.6 & 6.7 & 0.9 & 0.008 & 106 & 1063 & 10.9 & 158.4 \\
\hline$U$ & 366 & 0.0086 & 0.0228 & 0.0025 & 0.0001 & 0.27 & 2654 & 7.8 & 73.6 \\
\hline V & 366 & 0.22 & 0.37 & 0.13 & 0.003 & 4.6 & 460 & 6.2 & 58.3 \\
\hline $\mathrm{Zn}$ & 366 & 3.5 & 6.2 & 1.7 & 0.002 & 63.1 & 631 & 5.4 & 38.4 \\
\hline $\mathrm{Ca}^{2+}$ & 332 & $0.51 \times 10^{3}$ & $0.84 \times 10^{3}$ & $0.23 \times 10^{3}$ & 4 & $7.4 \times 10^{3}$ & 1862 & 4.3 & 24.5 \\
\hline $\mathrm{Cl}^{-}$ & 365 & 162 & $0.33 \times 10^{3}$ & 70 & 5 & $4.0 \times 10^{3}$ & 800 & 6.5 & 58.0 \\
\hline $\mathrm{K}^{+}$ & 153 & 114 & $0.29 \times 10^{3}$ & 32 & 1 & $2.7 \times 10^{3}$ & 2700 & 5.9 & 43.3 \\
\hline $\mathrm{Mg}^{2+}$ & 302 & 102 & 133 & 63 & 4 & $1.1 \times 10^{3}$ & 282 & 4.0 & 23.4 \\
\hline $\mathrm{Na}^{+}$ & 325 & 112 & $0.24 \times 10^{3}$ & 37 & 1 & $2.7 \times 10^{3}$ & 2729 & 6.1 & 52.6 \\
\hline $\mathrm{NO}_{3}^{-}$ & 366 & $0.90 \times 10^{3}$ & $0.81 \times 10^{3}$ & $0.64 \times 10^{3}$ & 27 & $5.4 \times 10^{3}$ & 198 & 2.1 & 6.2 \\
\hline $\mathrm{SO}_{4}^{2-}$ & 362 & $0.53 \times 10^{3}$ & $1.3 \times 10^{3}$ & $0.31 \times 10^{3}$ & 15 & $22.3 \times 10^{3}$ & 1488 & 13.9 & 230.3 \\
\hline
\end{tabular}

Atmospheric trace elements in Alpine snow

P. Gabrielli et al.

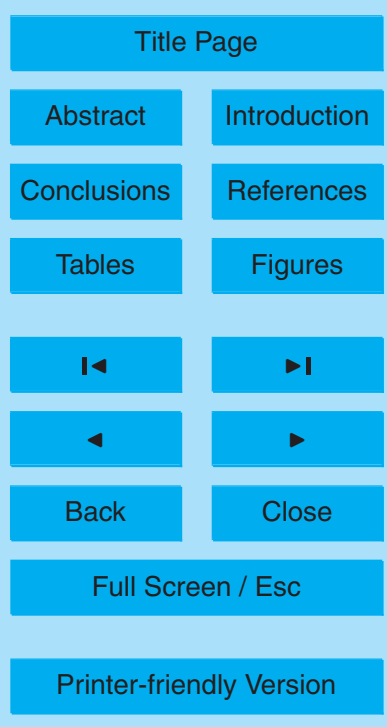

Interactive Discussion 


\section{ACPD}

$6,8781-8815,2006$

Table 3. Mean trace elements and major ions fluxes to the snow and the deviation of the two mean fluxes averaged for each of the two selected periods of dry deposition (data from 19 January-4 February; 24 February-11 March on sites $\mathrm{N}^{\circ} 11$ Mount Presena (3040 m) in Trentino, $\mathrm{N}^{\circ} 14$ Ravales $(2615 \mathrm{~m}), \mathrm{N}^{\circ} 15$ Mounts of Ornella $(2250 \mathrm{~m})$ and $\mathrm{N}^{\circ} 16$ Mount Pradazzo $(2200 \mathrm{~m})$ in Veneto).

\begin{tabular}{llllll}
\hline & $\begin{array}{l}\text { Flux } \\
\mathrm{g} \mathrm{ha}^{-1} \mathrm{yr}^{-1}\end{array}$ & $\begin{array}{l}\text { Deviation } \\
\mathrm{g} \mathrm{ha}^{-1} \mathrm{yr}^{-1}\end{array}$ & & $\begin{array}{l}\text { Flux } \\
\mathrm{g} \mathrm{ha}^{-1} \mathrm{yr}^{-1}\end{array}$ & $\begin{array}{l}\text { Deviation } \\
\mathrm{g} \mathrm{ha}^{-1} \mathrm{yr}^{-1}\end{array}$ \\
\hline $\mathrm{Ag}$ & 0.011 & 0.003 & $\mathrm{Ti}$ & 9 & 2 \\
$\mathrm{Bi}$ & 0.017 & 0.003 & $\mathrm{Mn}$ & 9 & 2 \\
$\mathrm{U}$ & 0.02 & 0.01 & $\mathrm{Zn}$ & 19 & 2 \\
$\mathrm{Mo}$ & 0.12 & 0.05 & $\mathrm{~K}+$ & 34 & 11 \\
$\mathrm{Cd}$ & 0.09 & 0.03 & $\mathrm{Fe}$ & 68 & 25 \\
$\mathrm{Co}$ & 0.14 & 0.03 & & & \\
$\mathrm{Sb}$ & 0.19 & 0.05 & $\mathrm{Na}^{+}$ & 243 & 122 \\
$\mathrm{~V}$ & 0.5 & 0.3 & $\mathrm{Mg}^{2+}$ & 254 & 58 \\
$\mathrm{Cr}$ & 0.27 & 0.03 & $\mathrm{Cl}^{-}$ & 240 & 7 \\
$\mathrm{Cu}$ & 1.4 & 0.4 & $\mathrm{SO}_{4}^{2-}$ & 1314 & 289 \\
$\mathrm{Ba}$ & 2 & 1 & $\mathrm{Ca}^{2+}$ & 1454 & 363 \\
$\mathrm{~Pb}$ & 4.2 & 0.3 & $\mathrm{NO}_{3}^{-}$ & 2797 & 280 \\
\hline
\end{tabular}

Atmospheric trace elements in Alpine snow

P. Gabrielli et al.

Title Page

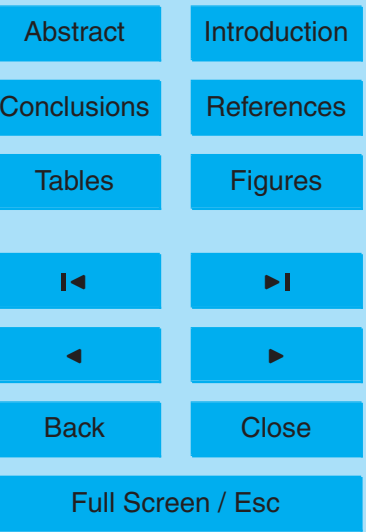

Printer-friendly Version

Interactive Discussion 


\section{ACPD}

$6,8781-8815,2006$

Table 4. Mean concentrations (ppb) of trace metals and major ions at the sampling sites in the Eastern Alps.

\begin{tabular}{|c|c|c|c|c|c|c|c|c|c|c|c|c|c|c|c|c|c|c|c|c|c|}
\hline & 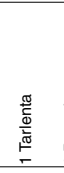 & 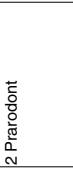 & 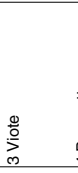 & 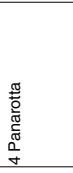 & 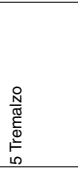 & 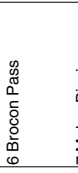 & 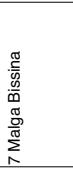 & 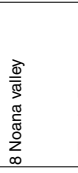 & 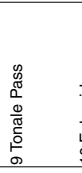 & 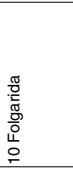 & 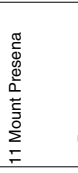 & 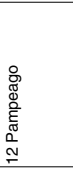 & 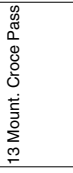 & 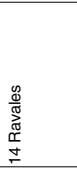 & 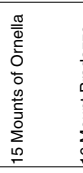 & 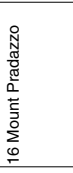 & 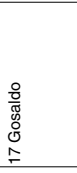 & 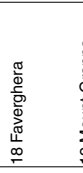 & 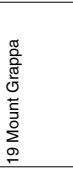 & 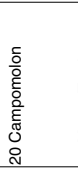 & 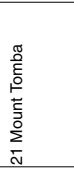 \\
\hline $\mathrm{Ag}$ & 0.005 & 0.005 & 0.007 & 0.003 & 0.002 & 0.003 & 0.007 & 0.003 & 0.011 & 0.003 & 0.005 & 0.004 & 0.004 & 0.004 & 0.002 & 0.002 & 0.002 & 0.007 & 0.005 & 0.004 & 0.004 \\
\hline $\mathrm{Ba}$ & 0.6 & 1.7 & 1.7 & 1.4 & 0.9 & 0.6 & 2.7 & 0.7 & 3.9 & 2.4 & 0.4 & 0.8 & 2.0 & 0.5 & 0.5 & 0.4 & 0.6 & 1.5 & 1.2 & 0.8 & 0.5 \\
\hline $\mathrm{Bi}$ & 0.002 & 0.007 & 0.004 & 0.009 & 0.003 & 0.004 & 0.015 & 0.004 & 0.013 & 0.005 & 0.003 & 0.004 & 0.004 & 0.004 & 0.002 & 0.002 & 0.003 & 0.010 & 0.009 & 0.006 & 0.004 \\
\hline $\mathrm{Cd}$ & 0.046 & 0.071 & 0.050 & 0.079 & 0.068 & 0.070 & 0.070 & 0.053 & 0.088 & 0.077 & 0.054 & 0.051 & 0.063 & 0.064 & 0.044 & 0.042 & 0.048 & 0.067 & 0.054 & 0.056 & 0.046 \\
\hline Co & 0.052 & 0.039 & 0.052 & 0.026 & 0.037 & 0.030 & 0.069 & 0.036 & 0.216 & 0.048 & 0.045 & 0.045 & 0.022 & 0.043 & 0.025 & 0.019 & 0.021 & 0.046 & 0.036 & 0.032 & 0.030 \\
\hline $\mathrm{Cr}$ & 0.050 & 0.084 & 0.116 & 0.083 & 0.061 & 0.060 & 0.154 & 0.031 & 0.398 & 0.067 & 0.065 & 0.072 & 0.047 & 0.077 & 0.071 & 0.052 & 0.080 & 0.186 & 0.116 & 0.090 & 0.053 \\
\hline $\mathrm{Cu}$ & 0.42 & 0.89 & 0.57 & 0.72 & 0.43 & 0.31 & 1.04 & 0.17 & 3.13 & 1.05 & 0.25 & 0.64 & 0.48 & 0.30 & 0.27 & 0.25 & 0.38 & 0.92 & 0.86 & 0.91 & 0.44 \\
\hline $\mathrm{Fe}$ & 18.7 & 26.0 & 46.3 & 14.1 & 17.1 & 13.4 & 59.7 & 15.5 & 113.7 & 23.2 & 12.7 & 26.3 & 13.0 & 14.5 & 15.6 & 11.2 & 10.7 & 36.8 & 27.0 & 15.2 & 11.4 \\
\hline $\mathrm{Mn}$ & 3.0 & 8.9 & 1.3 & 5.4 & 1.0 & 1.7 & 4.5 & 3.1 & 8.9 & 28.0 & 1.4 & 2.5 & 1.7 & 1.7 & 2.0 & 1.6 & 2.8 & 3.7 & 2.1 & 2.1 & 1.5 \\
\hline Mo & 0.044 & 0.049 & 0.061 & 0.051 & 0.047 & 0.038 & 0.066 & 0.039 & 0.130 & 0.061 & 0.039 & 0.047 & 0.047 & 0.052 & 0.031 & 0.028 & 0.030 & 0.060 & 0.057 & 0.053 & 0.042 \\
\hline $\mathrm{Pb}$ & 0.7 & 2.7 & 1.8 & 1.5 & 1.3 & 1.1 & 3.6 & 1.0 & 4.7 & 2.9 & 0.8 & 1.4 & 1.4 & 1.2 & 0.7 & 0.6 & 0.9 & 3.0 & 2.5 & 1.7 & 1.2 \\
\hline $\mathrm{Sb}$ & 0.022 & 0.044 & 0.065 & 0.041 & 0.038 & 0.034 & 0.076 & 0.027 & 0.562 & 0.053 & 0.026 & 0.045 & 0.043 & 0.052 & 0.030 & 0.023 & 0.029 & 0.082 & 0.073 & 0.057 & 0.045 \\
\hline $\mathrm{Ti}$ & 0.8 & 1.8 & 4.1 & 0.8 & 3.7 & 1.9 & 3.0 & 1.3 & 9.3 & 2.3 & 0.9 & 2.5 & 2.3 & & 1.3 & 1.4 & 3.1 & & & & 0.9 \\
\hline u & 0.0064 & 0.0084 & 0.0147 & 0.0030 & 0.0073 & 0.0038 & 0.0293 & 0.0041 & 0.0226 & 0.0087 & 0.0038 & 0.0066 & 0.0069 & 0.0058 & 0.0042 & 0.0025 & 0.0030 & 0.0128 & 0.0085 & 0.0057 & 0.0034 \\
\hline v & 0.09 & 0.18 & 0.23 & 0.18 & 0.18 & 0.12 & 0.28 & 0.07 & 0.74 & 0.20 & 0.10 & 0.13 & 0.13 & 0.21 & 0.10 & 0.09 & 0.15 & 0.48 & 0.38 & 0.26 & 0.23 \\
\hline $\mathrm{Zn}$ & 1.9 & 4.2 & 2.5 & 3.5 & 2.4 & 1.5 & 9.5 & 0.6 & 7.4 & 5.8 & 3.7 & 2.1 & 2.8 & 3.3 & 1.9 & 2.0 & 1.6 & 3.6 & 3.2 & 3.7 & 2.3 \\
\hline $\mathrm{Ca}^{2+}$ & 149 & 214 & 772 & 177 & 1713 & 425 & 226 & 721 & 848 & 297 & 88 & 439 & 670 & 527 & 430 & 478 & 885 & 618 & 494 & 301 & 437 \\
\hline $\mathrm{Cl}^{-}$ & 66 & 81 & 349 & 87 & 402 & 140 & 93 & 45 & 219 & 160 & 65 & 133 & 122 & 82 & 74 & 71 & 73 & 247 & 448 & 101 & 286 \\
\hline $\mathrm{K}^{+}$ & 43 & 115 & 27 & 224 & 42 & 198 & 22 & 126 & 119 & 501 & 20 & 45 & 56 & 20 & 17 & 31 & 31 & 129 & 47 & 22 & 33 \\
\hline $\mathrm{Mg}^{2+}$ & 59 & 53 & 164 & 58 & 72 & 79 & 46 & 137 & 101 & 80 & 29 & 160 & 137 & 100 & 104 & 87 & 130 & 161 & 168 & 88 & 74 \\
\hline $\mathrm{Na}^{+}$ & 43 & 54 & 202 & 40 & 298 & 96 & 53 & 17 & 155 & 81 & 47 & 92 & 126 & 47 & 41 & 127 & 42 & 138 & 330 & 62 & 170 \\
\hline $\mathrm{NO}_{3}^{-}$ & 743 & 752 & 888 & 786 & 947 & 904 & 858 & 261 & 1132 & 1054 & 609 & 858 & 961 & 728 & 946 & 1017 & 760 & 1288 & 1371 & 795 & 1047 \\
\hline $\mathrm{SO}_{4}^{2-}$ & 282 & 316 & 395 & 392 & 675 & 295 & 383 & 154 & 615 & 396 & 384 & 630 & 1157 & 382 & 320 & 404 & 295 & 1774 & 596 & 451 & 703 \\
\hline
\end{tabular}

\section{Atmospheric trace} elements in Alpine snow

P. Gabrielli et al.

Title Page

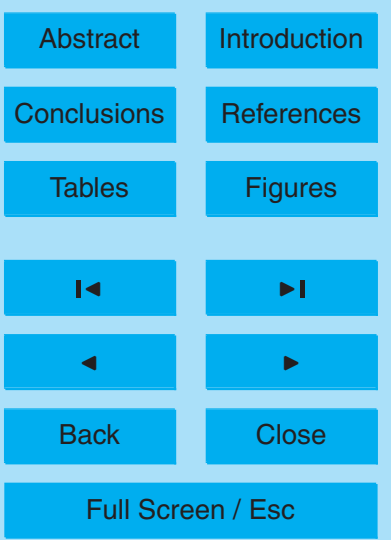

Printer-friendly Version

Interactive Discussion 


\section{ACPD}

$6,8781-8815,2006$

\section{Atmospheric trace} elements in Alpine snow

P. Gabrielli et al.

Table 5. Variance distribution of the first three extracted principal components.

\begin{tabular}{lllll}
\hline Component & Variance & Variance $\%$ & Cumulative variance & Cumulative variance \% \\
\hline 1 & 13,48 & 61 & 13,48 & 61 \\
2 & 2,15 & 10 & 15,63 & 71 \\
3 & 1,29 & 6 & 16,93 & 77 \\
\hline
\end{tabular}

Title Page

Abstract

Introduction

Conclusions

References

Tables

Figures

14

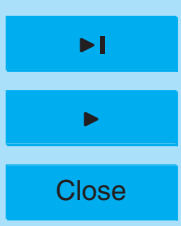

Back

Close 
Table 6. Scores of the first three factors and cumulative communality of each chemical variable.

\begin{tabular}{lllll}
\hline & $\mathrm{P} 1$ & $\mathrm{P} 2$ & $\mathrm{P} 3$ & Com. \\
\hline $\mathrm{Ag}$ & 0.74 & 0.02 & -0.15 & 0.57 \\
$\mathrm{Ba}$ & 0.84 & 0.12 & 0.39 & 0.88 \\
$\mathrm{Bi}$ & 0.87 & 0.11 & 0.13 & 0.78 \\
$\mathrm{Cd}$ & 0.67 & 0.27 & -0.07 & 0.52 \\
$\mathrm{Co}$ & 0.79 & 0.09 & 0.29 & 0.71 \\
$\mathrm{Cr}$ & 0.82 & 0.16 & 0.26 & 0.77 \\
$\mathrm{Cu}$ & 0.84 & 0.21 & 0.34 & 0.87 \\
$\mathrm{Fe}$ & 0.86 & 0.05 & 0.42 & 0.92 \\
$\mathrm{Mn}$ & 0.76 & 0.18 & 0.43 & 0.79 \\
$\mathrm{Mo}$ & 0.84 & 0.22 & 0.13 & 0.76 \\
$\mathrm{~Pb}$ & 0.91 & 0.20 & 0.18 & 0.91 \\
$\mathrm{Sb}$ & 0.86 & 0.36 & 0.11 & 0.88 \\
$\mathrm{Ti}$ & 0.69 & 0.05 & 0.59 & 0.82 \\
$\mathrm{U}$ & 0.79 & 0.08 & 0.53 & 0.91 \\
$\mathrm{~V}$ & 0.79 & 0.38 & 0.13 & 0.78 \\
$\mathrm{Zn}$ & 0.76 & 0.35 & 0.29 & 0.78 \\
$\mathrm{Ca}^{2+}$ & 0.37 & 0.26 & 0.75 & 0.76 \\
$\mathrm{Cl}^{-}$ & 0.30 & 0.71 & 0.42 & 0.76 \\
$\mathrm{Mg}^{2+}$ & 0.30 & 0.26 & 0.72 & 0.67 \\
$\mathrm{Na}^{+}$ & 0.13 & 0.68 & 0.42 & 0.66 \\
$\mathrm{NO}_{3}^{-}$ & 0.16 & 0.80 & 0.15 & 0.69 \\
$\mathrm{SO}_{4}^{2-}$ & 0.18 & 0.83 & -0.06 & 0.73 \\
\hline
\end{tabular}

\section{6, 8781-8815, 2006}

\section{Atmospheric trace} elements in Alpine snow

\section{P. Gabrielli et al.}

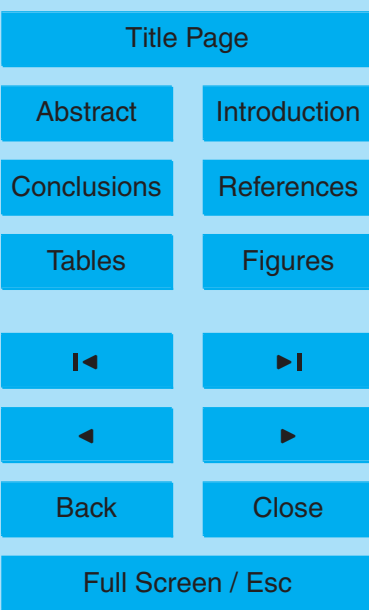

Printer-friendly Version

Interactive Discussion 


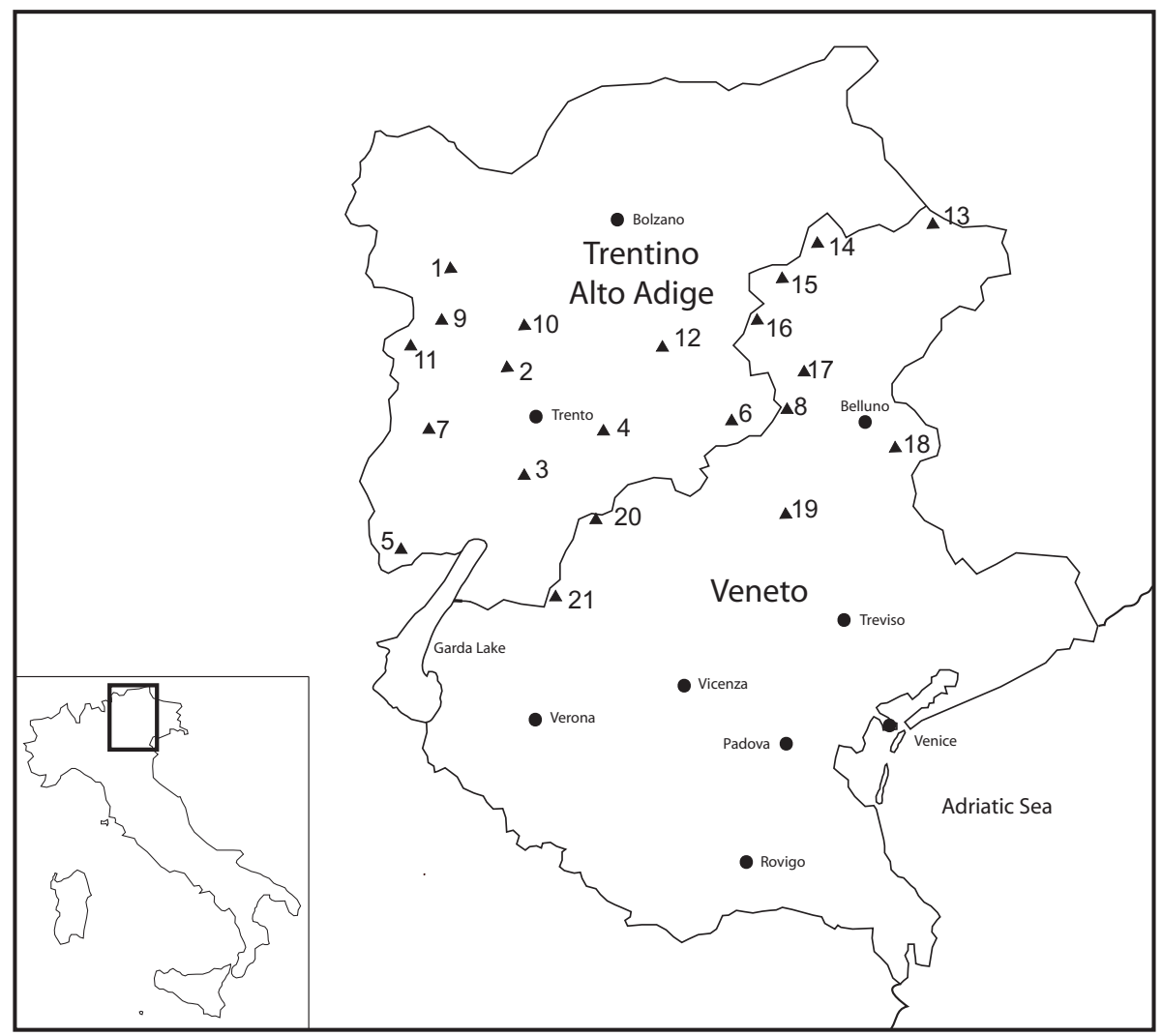

Fig. 1. Sampling area in Trentino and Veneto (Italy).

\section{ACPD}

6, 8781-8815, 2006

\section{Atmospheric trace} elements in Alpine snow

P. Gabrielli et al.

Title Page

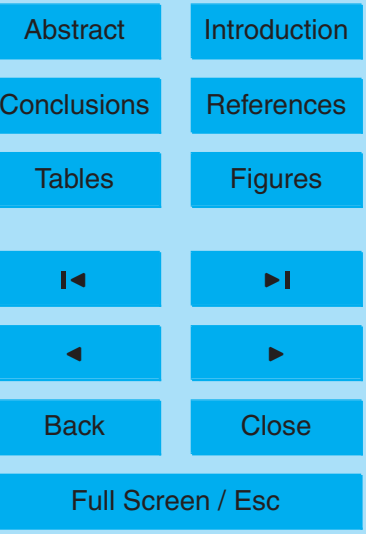

Printer-friendly Version

Interactive Discussion 


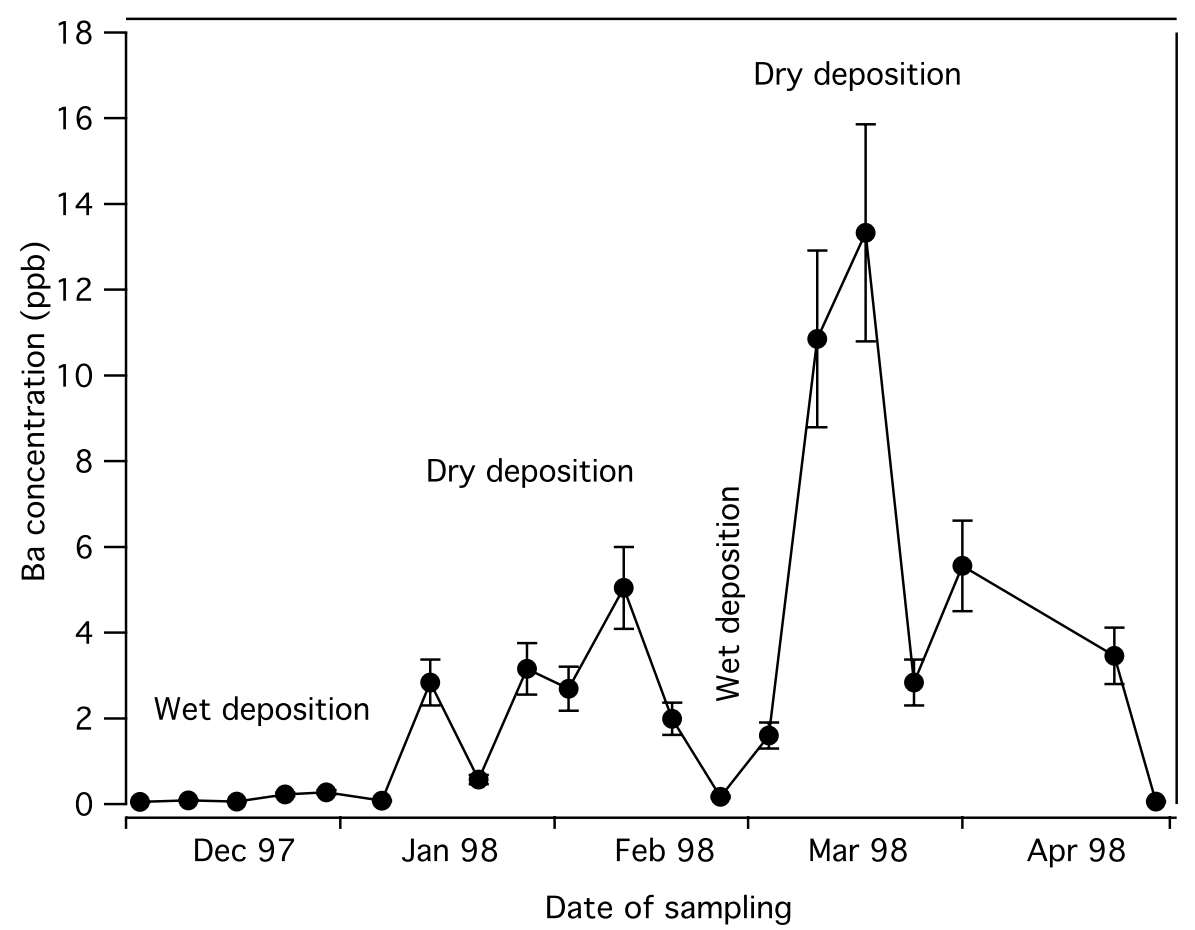

Fig. 2. Ba temporal profile at Malga Bissina $(1780 \mathrm{~m}$, Trentino) showing the sequence of wet deposition (low values) and dry deposition (high values), which is essentially representative for most of the chemical variables at most of the sampling sites.

\section{$6,8781-8815,2006$}

\section{Atmospheric trace} elements in Alpine snow

P. Gabrielli et al.

Title Page

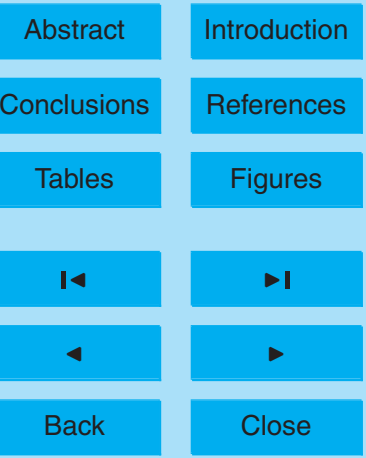

Full Screen / Esc

Printer-friendly Version

Interactive Discussion 


\section{ACPD}

6, 8781-8815, 2006

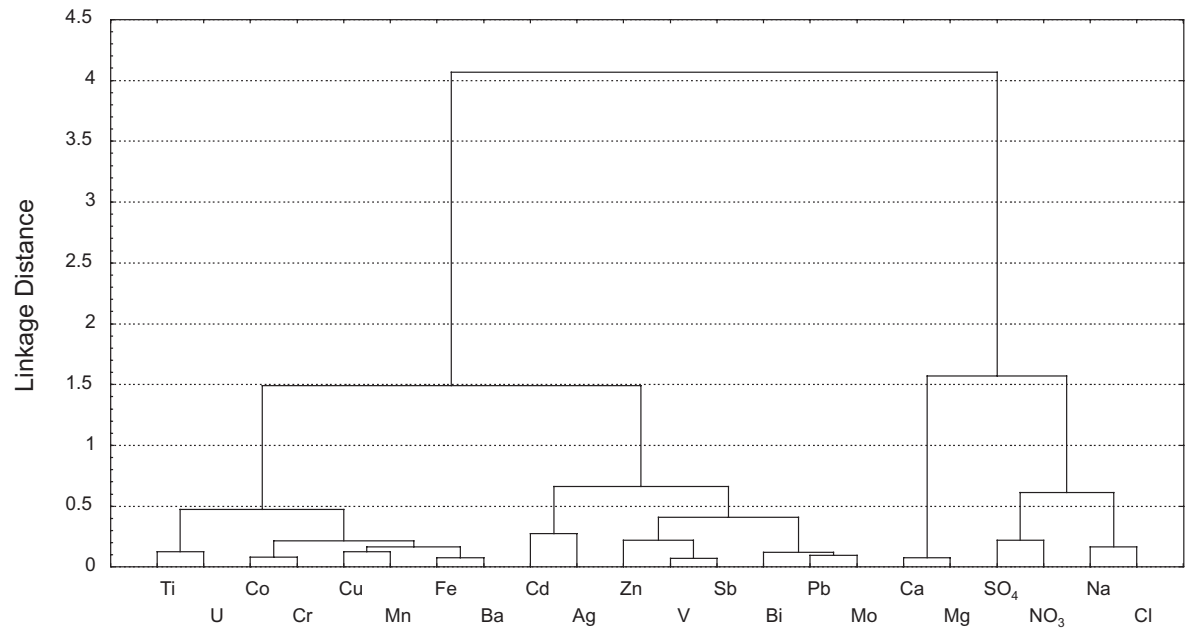

Atmospheric trace elements in Alpine snow

P. Gabrielli et al.

Title Page

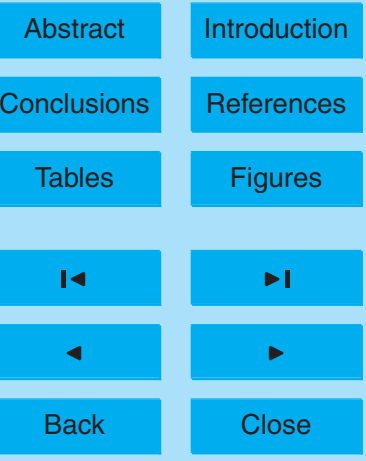

Full Screen / Esc

Printer-friendly Version

Interactive Discussion 